Prepared in cooperation with the Hopi Tribe

\title{
Quality, Isotopes, and Radiochemistry of Water Sampled from the Upper Moenkopi Village Water-Supply Wells, Coconino County, Arizona
}

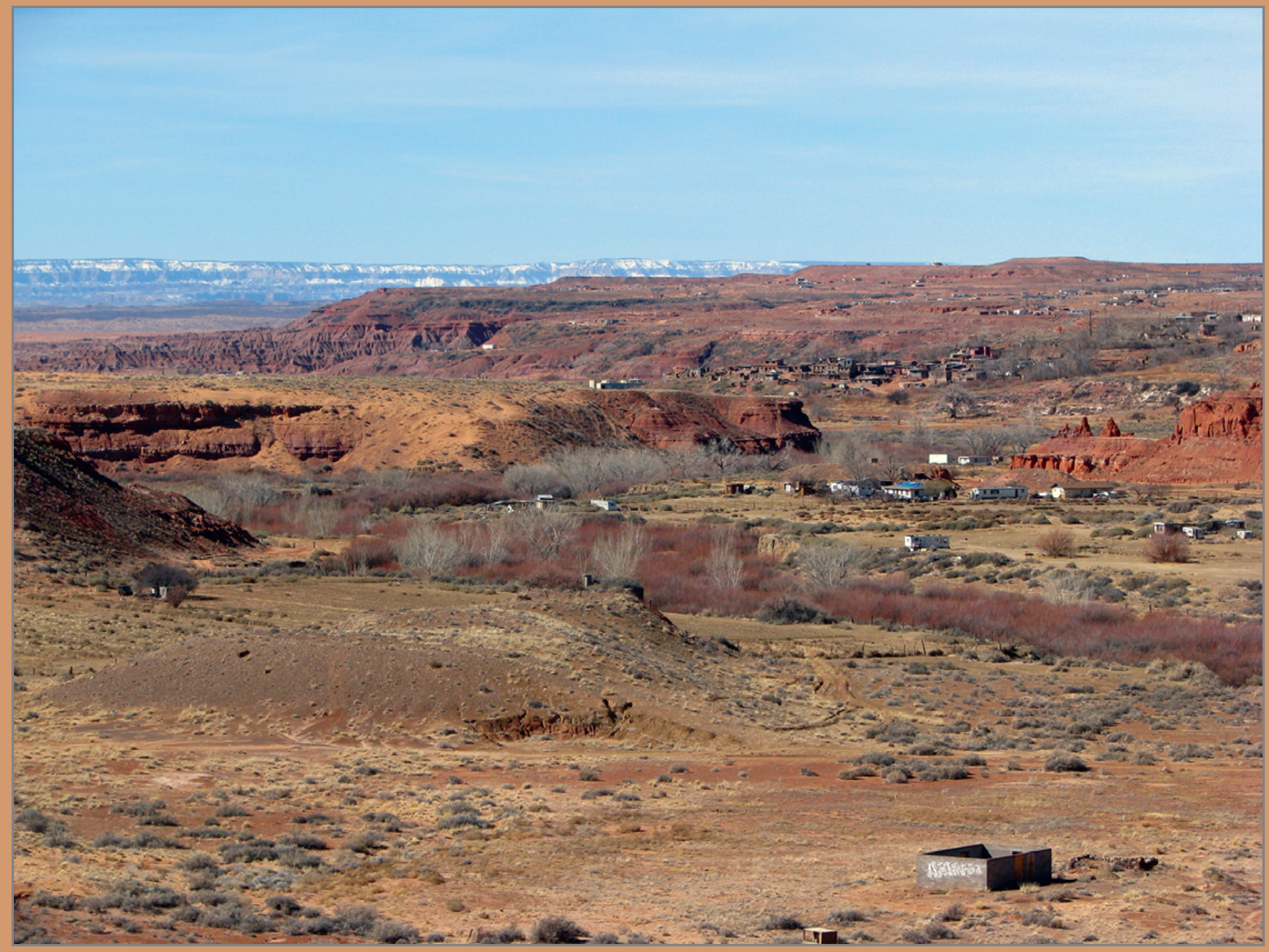

Open-File Report 2013-1162 
FRONT COVER

Overview of Upper and Lower Moenkopi Villages from the south looking north across Moenkopi Wash. Photograph taken by D.J. Bills, Fall 2008. 


\section{Quality, Isotopes, and Radiochemistry of Water Sampled from the Upper Moenkopi Village Water-Supply Wells, Coconino County, Arizona}

By Robert L. Carruth, Kimberly Beisner, and Greg Smith

Prepared in cooperation with the Hopi Tribe

Open-File Report 2013-1162 


\section{U.S. Department of the Interior SALLY JEWELL, Secretary}

\section{U.S. Geological Survey \\ Suzette M. Kimball, Acting Director}

U.S. Geological Survey, Reston, Virginia: 2013

For product and ordering information: World Wide Web: http://www.usgs.gov/pubprod Telephone: 1-888-ASK-USGS

For more information on the USGS - the Federal source for science about the Earth, its natural and living resources, natural hazards, and the environment: World Wide Web: http://www.usgs.gov

Telephone: 1-888-ASK-USGS

Any use of trade, firm, or product names is for descriptive purposes only and does not imply endorsement by the U.S. Government.

Although this information product, for the most part, is in the public domain, it also may contain copyrighted materials as noted in the text. Permission to reproduce copyrighted items must be secured from the copyright owner.

Suggested citation:

Carruth, R.L., Beisner, Kimberly, and Smith, Greg, 2013, Qualilty, isotopes, and radiochemistry of water sampled from the Upper Moenkopi Village water-supply wells, Coconino County, Arizona: U.S. Geological Survey Open-File Report 2013-1162, $18 p$. 


\section{Contents}

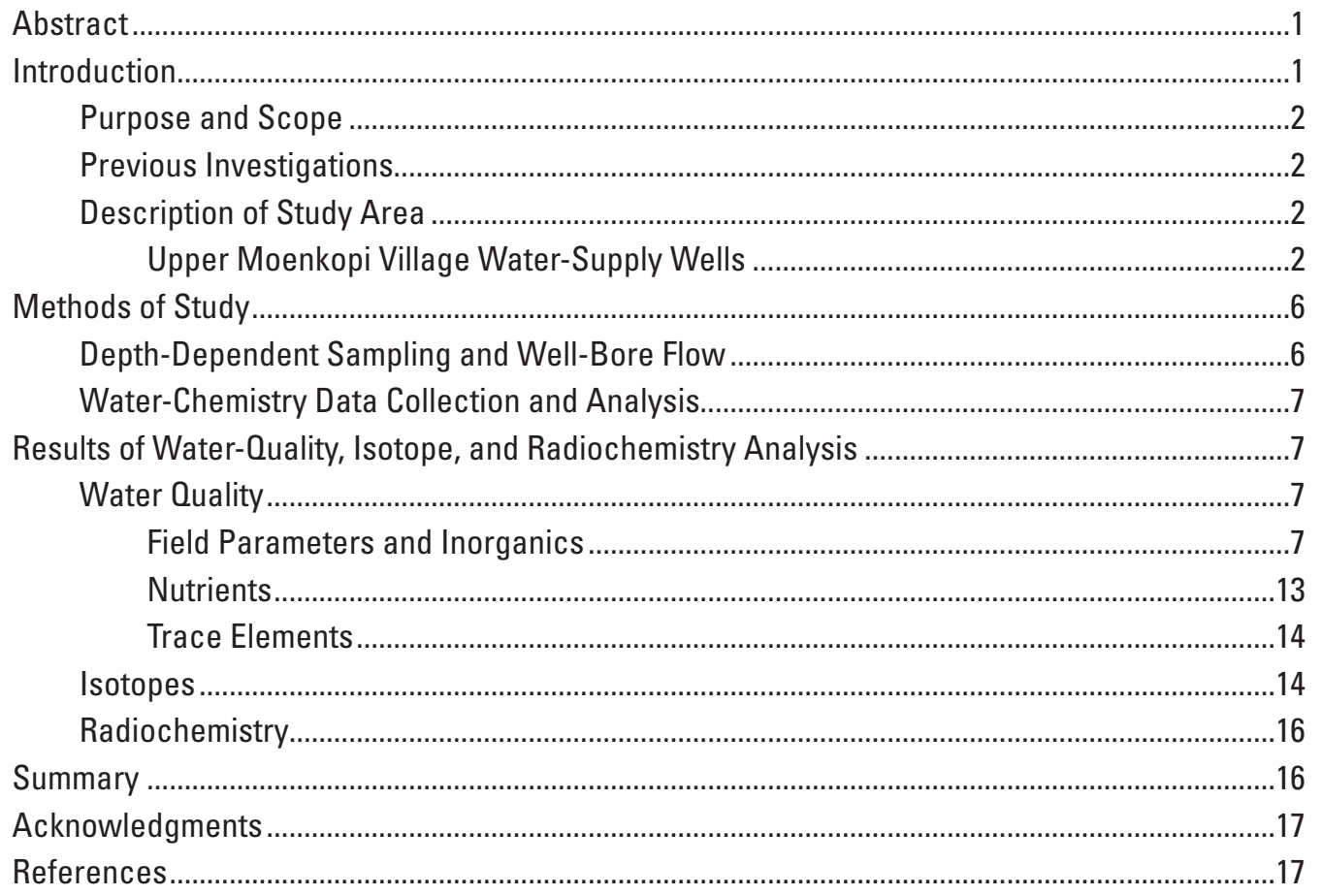

\section{Figures}

1. Map showing location of the study area in northeastern Arizona ...

2. Map showing Upper Moenkopi water-supply wells near the Moenkopi Villages,

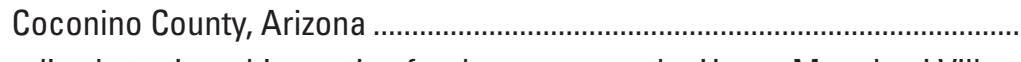

3. Generalized stratigraphic section for the area near the Upper Moenkopi Village water-supply wells, Coconino County, Arizona

4. Trilinear diagram showing relative compositions of groundwater samples collected from the Upper Moenkopi Village water-supply wells in Coconino County, Arizona......12

5. Graph showing oxygen-18 $\left({ }^{18} \mathrm{O}\right)$ and deuterium $\left({ }^{2} \mathrm{H}\right)$ data from the Upper Moenkopi Village water-supply wells and comparison with other water sources in the surrounding area, Coconino County, Arizona

\section{Tables}

1. Construction, water-level, and pumping data from the Upper Moenkopi Village water-supply wells, Coconino County, Arizona ...

2. Water quality data from Upper Moenkopi Village water-supply wells, Coconino County, Arizona .8

3. Carbon-14 radioisotope data used to estimate ages of groundwater sampled from the upper Moenkopi Village water-supply wells, Coconino County, Arizona. 


\section{Conversion Factors}

\begin{tabular}{|c|c|c|}
\hline \multicolumn{3}{|c|}{ Inch/Pound to SI } \\
\hline Multiply & By & To obtain \\
\hline \multicolumn{3}{|c|}{ Length } \\
\hline inch (in.) & 2.54 & centimeter $(\mathrm{cm})$ \\
\hline inch (in.) & 25.4 & millimeter $(\mathrm{mm})$ \\
\hline foot $(\mathrm{ft})$ & 0.3048 & meter $(\mathrm{m})$ \\
\hline mile (mi) & 1.609 & kilometer $(\mathrm{km})$ \\
\hline \multicolumn{3}{|c|}{ Volume } \\
\hline gallon (gal) & 3.785 & liter (L) \\
\hline gallon (gal) & 0.003785 & cubic meter $\left(\mathrm{m}^{3}\right)$ \\
\hline gallon (gal) & 3.785 & cubic decimeter $\left(\mathrm{dm}^{3}\right)$ \\
\hline \multicolumn{3}{|c|}{ Flow rate } \\
\hline gallon per day (gal/d) & 0.003785 & cubic meter per day $\left(\mathrm{m}^{3} / \mathrm{d}\right)$ \\
\hline gallon per minute (gal/min) & 3.785 & liter per minute $(\mathrm{L} / \mathrm{min})$ \\
\hline \multicolumn{3}{|c|}{ Radioactivity } \\
\hline picocurie per liter $(\mathrm{pCi} / \mathrm{L})$ & 0.037 & becquerel per liter $(\mathrm{Bq} / \mathrm{L})$ \\
\hline \multicolumn{3}{|c|}{ SI to Inch/Pound } \\
\hline Multiply & By & To obtain \\
\hline millimeter (mm) & 0.03937 & inch (in.) \\
\hline \multicolumn{3}{|c|}{ Volume } \\
\hline liter (L) & 1.057 & quart $(\mathrm{qt})$ \\
\hline liter (L) & 0.2642 & gallon (gal) \\
\hline
\end{tabular}

Temperature in degrees Celsius $\left({ }^{\circ} \mathrm{C}\right)$ may be converted to degrees Fahrenheit $\left({ }^{\circ} \mathrm{F}\right)$ as follows: ${ }^{\circ} \mathrm{F}=\left(1.8 \times{ }^{\circ} \mathrm{C}\right)+32$

Vertical coordinate information is referenced to the North American Vertical Datum of 1988 (NAVD 88).

Horizontal coordinate information is referenced to the insert North American Datum of 1983 (NAD 83).

Altitude, as used in this report, refers to distance above the vertical datum.

Specific conductance is given in microsiemens per centimeter at 25 degrees Celsius $\left(\mu \mathrm{S} / \mathrm{cm}\right.$ at $\left.25^{\circ} \mathrm{C}\right)$.

Concentrations of chemical constituents in water are given either in milligrams per liter $(\mathrm{mg} / \mathrm{L})$ or micrograms per liter $(\mu \mathrm{g} / \mathrm{L})$. 


\title{
Quality, Isotopes, and Radiochemistry of Water Sampled from the Upper Moenkopi Village Water-Supply Wells, Coconino County, Arizona
}

\author{
By Robert L. Carruth, Kimberly Beisner, and Greg Smith
}

\section{Abstract}

The Hopi Tribe Water Resources Program has granted contracts for studies to evaluate water supply conditions for the Moenkopi villages in Coconino County, Arizona. The Moenkopi villages include Upper Moenkopi Village and the village of Lower Moencopi, both on the Hopi Indian Reservation south of the Navajo community of Tuba City. These investigations have determined that water supplies are limited and vulnerable to several potential sources of contamination, including the Tuba City Landfill and a former uranium processing facility known as the Rare Metals Mill. Studies are ongoing to determine if uranium and other metals in groundwater beneath the landfill are greater than regional groundwater concentrations.

The source of water supply for the Upper Moenkopi Village is three public-supply wells. The wells are referred to as MSW-1, MSW-2, and MSW-3 and all three wells obtain water from the regionally extensive $\mathrm{N}$ aquifer. The $\mathrm{N}$ aquifer is the principal aquifer in this region of northern Arizona and consists of thick beds of sandstone between less permeable layers of siltstone and mudstone. The relatively fine-grained character of the $\mathrm{N}$ aquifer inhibits rapid movement of water and large yields to wells. In recent years, water levels have declined in the three public-supply wells, causing concern that the current water supply will not be able to accommodate peak demand and allow for residential and economic growth.

Analyses of major ions, nutrients, selected trace metals, stable and radioactive isotopes, and radiochemistry were performed on the groundwater samples from the three publicsupply wells to describe general water-quality conditions and groundwater ages in and immediately surrounding the Upper Moenkopi Village area. None of the water samples collected from the public-supply wells exceeded the U.S. Environmental Protection Agency primary drinking water standards.

The ratios of the major dissolved ions from the samples collected from MSW-1 and MSW-2 indicate water with a major ion composition of calcium and sulfate. There is no significant vertical distribution of ion concentrations in the samples collected from the upper and lower portion of the water column within the two wells. The samples collected at
MSW-3 are higher in sodium and lower in calcium than the samples collected from MSW-1 and MSW-2, and contain a similar sulfate-ion percentage. There is a vertical distribution of ion concentrations in the samples collected from the upper and lower portion of the water column in MSW-3.

Groundwater samples from the three water-supply wells analyzed for oxygen-18 and deuterium stable isotopes plot on a local water line that is approximately parallel to the global meteoric water line. Tritium concentrations in samples from MSW-1 and MSW-3 were equal to or less than laboratory detection limits and were interpreted to contain no modern (post-1952) water. Tritium concentration in a sample from the top of the water column at MSW-2 was 0.41 tritium units, indicating that the composition is primarily pre-bomb (pre1952) water, but may contain a small fraction of post-bomb modern water.

The calculated carbon-14 ages of groundwater in MSW-1 and MSW-2, both completed about 140 feet into the Navajo Sandstone, are about 3,000 years before present. The calculated carbon-14 age of groundwater in MSW-3, completed about 240 feet into the Kayenta Formation-Navajo Sandstone transition zone is about 5,000 years before present in the upper portion of the water column and about 8,500 years before present in the lower portion of the water column. The gross alpha radioactivity of samples collected from the three water-supply wells ranged from 5.1 to 9.8 picocuries per liter-less than the U.S. Environmental Protection Agency primary drinking water standard of 15 picocuries per liter. The gross beta radioactivity of samples collected from the wells ranged from 0.9 to 2.8 picocuries per liter and are not considered elevated relative to the U.S. Environmental Protection Agency primary drinking water standard.

\section{Introduction}

In 2010, the Hopi Tribe and the Indian Health Service (IHS) requested assistance from the U.S. Geological Survey (USGS) in evaluating the source of water to the public water supply and water quality as it relates to the possible migration of contaminated groundwater to supply wells in the 
Upper Moenkopi Village area. Previous investigations have determined that local water supplies are limited and vulnerable to potential sources of contamination, including the Tuba City Landfill and a former uranium processing facility known as the Rare Metals Mill. Studies are ongoing to determine if uranium and other metals in groundwater beneath the landfill are greater than regional groundwater concentrations and if a flow path exists between the Tuba City Landfill area and the village water-supply wells.

This report documents the collection and analyses of depth-dependent water samples under pumping conditions from the three public water-supply wells in Upper Moenkopi Village, referred to as MSW-1, MSW-2, and MSW-3 (figs. 1 and 2). Samples from these wells were analyzed for a range of chemical and isotopic constituents including major ions, nutrients, trace elements, stable and radioactive isotopes, and radiochemistry. These data were collected to evaluate the quality of water that makes up the municipal water supply for Upper Moenkopi Village. The analytical results were reviewed to determine if degradation of water quality has occurred. The depth-dependent water-quality samples were analyzed to determine if any vertical distribution of water quality or contaminants exists within the Navajo Sandstone and Kayenta Formation (stratigraphic units of the $\mathrm{N}$ aquifer penetrated by the water-supply wells). Additionally, an attempt was made to collect well-bore flow data from the three wells to determine the flow distribution into the wells from the surrounding aquifer; however, limitations caused by the well construction and the relatively low permeability of the surrounding aquifer prohibited collection of well-bore flow data.

\section{Purpose and Scope}

The purpose of this report is to assess the source, distribution of flow, and quality of water from each of the three public water-supply wells under pumping conditions. Data collected during this study can be used to (1) assess the quality of the existing municipal water supply, (2) provide a baseline for comparison with future water-quality monitoring, (3) evaluate management options to address possible contaminant sources, and (4) provide information to design and locate future water-supply wells.

\section{Previous Investigations}

Previous investigations of the $\mathrm{N}$ aquifer have evaluated water availability for local needs. A study by Cooley and others (1969) provided the regional hydrogeologic characterization of the $\mathrm{N}$ aquifer in the Moenkopi and Tuba City area. Additional investigations by the USGS have added to this characterization over the years (Levings and Farrar, 1977; Farrar, 1980; Eychaner, 1983; Lopes and Hoffmann, 1997; Hoffmann and others, 2006; Macy, 2010; Macy and others, 2012). Additional studies have characterized the aquifer at the scale of individual test wells (Tetra Tech EM
Inc., 2004; Carruth and Bills, 2012). Local geology and geologic structure also has been investigated (Macy, 2012) and is important because it affects the occurrence and movement of groundwater and movement of potential contaminants in the area. Additionally, geologic maps and cross sections, and geochemical analyses of rock, sediment, and groundwater have been done in the vicinity of the Tuba City landfill (Johnson and Wirt, 2009; Otton and others, 2009).

\section{Description of Study Area}

Upper Moenkopi Village is on the Hopi Indian Reservation south of the Navajo Nation community of Tuba City and west of Pasture Canyon on the southern side of U.S. Highway 160, approximately 80 mi northeast of Flagstaff, Arizona (figs. 1 and 2). Upper Moenkopi Village is one of 12 villages that make up the communities of the Hopi Nation in northeastern Arizona. Exposed rocks in the study area include the Jurassic Navajo Sandstone, and eolian sand and dunes eroded from the Navajo Sandstone. The surface deposits are covered with sparse desert grasses, cactus, and sagebrush. The regional dip of rock units at the surface is about 2 degrees northeast toward the Tuba City syncline, whose axis is about 5 miles from the study area (Cooley and others, 1969).

\section{Upper Moenkopi Village Water-Supply Wells}

Water for the Upper Moenkopi Village is supplied from three wells (MSW-1, MSW-2, and MSW-3) completed in the regionally extensive $\mathrm{N}$ aquifer, the principal aquifer in this region of northern Arizona. The $\mathrm{N}$ aquifer is a moderately productive groundwater-flow system that underlies most of the Navajo and Hopi Indian Reservations in northern Arizona. The Moenkopi Villages, however, are at the western edge of the $\mathrm{N}$ aquifer where rock units of the groundwater-flow system are thinned by exposure and erosion or locally pinch out. The $\mathrm{N}$ aquifer is composed of thick beds of sandstone between less permeable layers of siltstone and mudstone. The relatively fine-grained character of the $\mathrm{N}$ aquifer inhibits rapid movement of water and large yields to wells. In recent years, water levels have declined in the three public-supply wells, causing concern that the current water supply will not be able to accommodate peak demand and allow for residential and economic growth.

The wells generally are aligned east-west along the southern side of, and approximately parallel to, Highway 160 (fig. 2). MSW-1 (easternmost well) and MSW-2 (westernmost well) are separated by a distance of approximately $500 \mathrm{ft}$. MSW-3 is between MSW-1 and MSW-2, but closer to MSW1. MSW-1 and MSW-2 were constructed in 1977 and 1982, respectively. Both wells were originally completed to about $140 \mathrm{ft}$ below land surface. MSW-3 was constructed in 1991 to a depth of $280 \mathrm{ft}$ below land surface. Construction details for the wells (including the screened intervals and depths to the pumps) were provided by the Hope Tribe Water Resources 


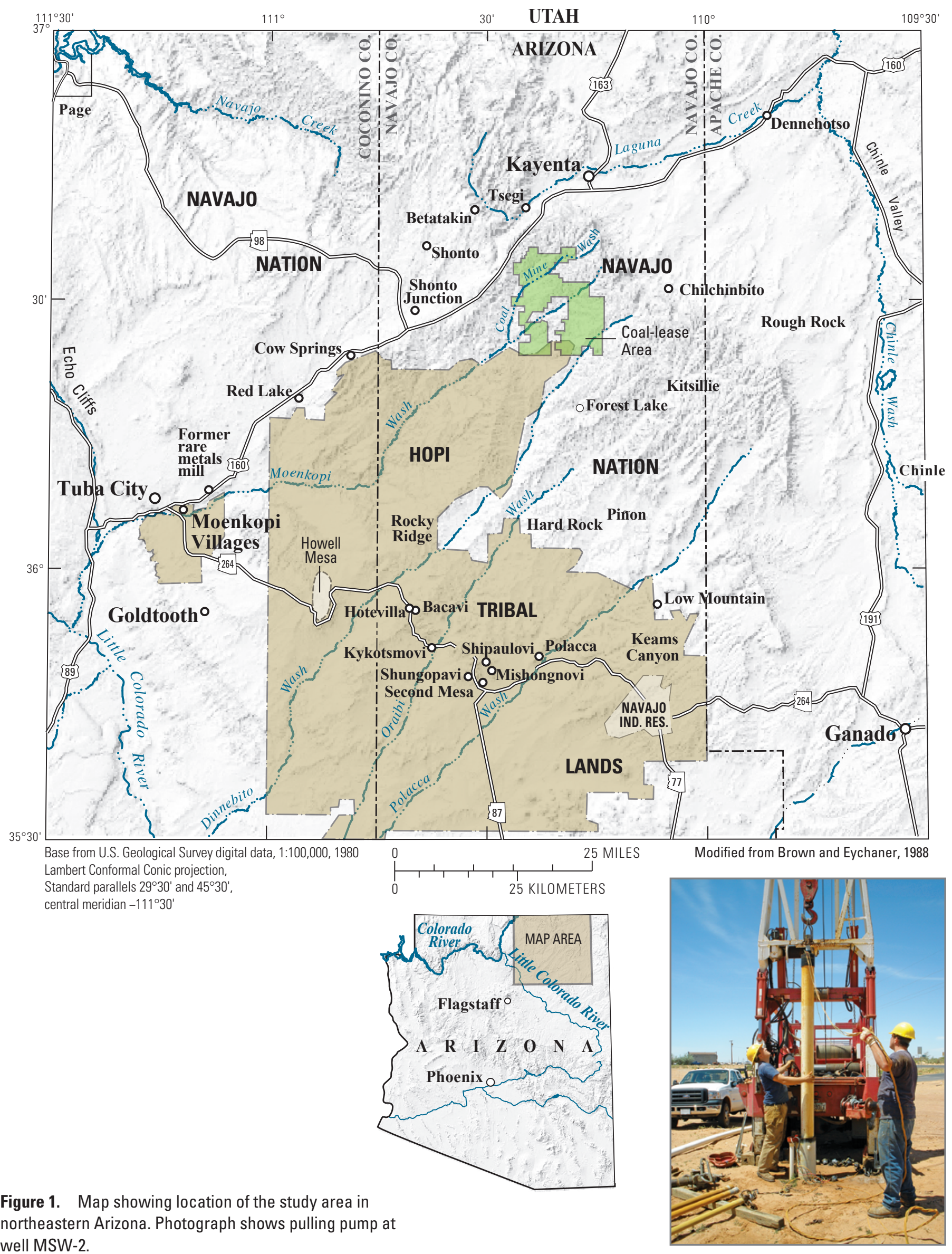






Base from U.S. Department of Agriculture, National Agriculture Imagery Program, Universal Transverse Mercator Projection, North American Datum 1983, Zone 12 North

Figure 2. Map showing Upper Moenkopi water-supply wells near the Moenkopi villages, Coconino County, Arizona. 
Table 1. Construction, water-level, and pumping data from the Upper Moenkopi Village water-supply wells, Coconino County, Arizona. [gpm, gallons per minute; ft, feet; water level and pumping data collected during fieldwork in April and May, 2010]

\begin{tabular}{|c|c|c|c|c|c|c|c|c|c|}
\hline $\begin{array}{l}\text { Year well } \\
\text { constructed }\end{array}$ & $\begin{array}{c}\text { USGS site } \\
\text { identification } \\
\text { number }\end{array}$ & $\begin{array}{c}\text { Local } \\
\text { identification } \\
\text { number }\end{array}$ & $\begin{array}{l}\text { Top of } \\
\text { casing } \\
\text { elevation } \\
\text { (ft) }\end{array}$ & $\begin{array}{l}\text { Depth to top } \\
\text { and bottom } \\
\text { of screened } \\
\text { interval(s) } \\
\text { (ft) }\end{array}$ & $\begin{array}{l}\text { Constructed } \\
\text { depth and } \\
\text { actual depth } \\
\text { to bottom of } \\
\text { well (ft) }\end{array}$ & $\begin{array}{l}\text { Depth to } \\
\text { top of } \\
\text { pump } \\
\text { (ft) }\end{array}$ & $\begin{array}{c}\text { Static } \\
\text { depth } \\
\text { to water }{ }^{1} \\
\text { (ft) } \\
\text { and date }\end{array}$ & $\begin{array}{c}\text { Pumping } \\
\text { depth } \\
\text { to water }{ }^{1} \\
\text { (ft) } \\
\text { and date }\end{array}$ & $\begin{array}{c}\text { Pumping } \\
\text { discharge } \\
\text { (gpm) and } \\
\text { date }\end{array}$ \\
\hline \multicolumn{10}{|c|}{ Upper Moenkopi Village water-supply well name } \\
\hline \multicolumn{10}{|c|}{ MSW-1 } \\
\hline \multicolumn{10}{|c|}{ MSW-2 } \\
\hline 1982 & 360719111130401 & $\begin{array}{l}\text { A-32-11 } \\
\text { 28DCA }\end{array}$ & 4,846 & $\begin{array}{c}72-77 \\
105-125 \\
\text { (perforated } \\
\text { intervals are } \\
\text { 8-inch stainless } \\
\text { steel } \\
\text { well screen) }\end{array}$ & $\begin{array}{c}142 \\
\text { (backfilled } \\
\text { with } \\
\text { sediment to } \\
127 \text { ) }\end{array}$ & 109 & $\begin{array}{c}79.7 \\
\text { May 5, } \\
2010\end{array}$ & $\begin{array}{c}100^{2} \\
\text { April 28, } \\
2010\end{array}$ & $\begin{array}{c}25 \\
\text { May 12, } \\
2010\end{array}$ \\
\hline \multicolumn{10}{|c|}{ MSW-3 } \\
\hline 1991 & 360719111130001 & $\begin{array}{c}\text { A-32-11 } \\
28 D C A 3\end{array}$ & 4,845 & $\begin{array}{c}71-81 \\
125-145 \\
166-176 \\
226-236 \\
\text { (perforated } \\
\text { intervals are } \\
\text { 8-inch stainless } \\
\text { steel } \\
\text { well screen) }\end{array}$ & $\begin{array}{l}280 \\
\text { (backfilled } \\
\text { with } \\
\text { sediment to } \\
\text { 241) }\end{array}$ & 220 & $\begin{array}{c}72.75 \\
\text { May 5, } \\
2010\end{array}$ & $\begin{array}{c}88.5 \\
\text { April 28, } \\
2010\end{array}$ & $\begin{array}{c}10 \\
\text { April 28, } \\
2010\end{array}$ \\
\hline
\end{tabular}

\footnotetext{
${ }^{1}$ Measuring point at top of well casing

${ }^{2}$ Measurement error possible due to cascading water
}

Program and water levels were measured by the USGS during the fieldwork in April and May 2010 (table 1).

The wells produce groundwater from the Navajo Sandstone and the upper part of the Kayenta FormationNavajo Sandstone transition zone, both units of the $\mathrm{N}$ aquifer (fig. 3). MSW-1 produced $60 \mathrm{gal} / \mathrm{min}$ upon completion in June 1977. The well discharge decreased to about $45 \mathrm{gal} / \mathrm{min}$ by October 2007, and was measured at $42.5 \mathrm{gal} / \mathrm{min}$ on May 5 , 2010. MSW-2 produced about $40 \mathrm{gal} / \mathrm{min}$ upon completion in February 1982 and was measured at $25 \mathrm{gal} / \mathrm{min}$ on May 12 , 2010. MSW-3 has been the lowest producing well of the three supply wells from the time it was completed in 1991. The well was originally reported to be capable of producing about $35 \mathrm{gal} / \mathrm{min}$, but discharge has decreased with time; discharge at MSW-3 was measured at $8 \mathrm{gal} / \mathrm{min}$ in October 2007, and was measured at $10 \mathrm{gal} / \mathrm{min}$ on April 28, 2010. Water levels in the three wells also have declined in recent years (U.S. Department of Health and Human Services, 2008).

The close spacing of the wells may be leading to additional drawdown and decreased production from well interference when the wells are operated simultaneously. As a result, Upper Moenkopi Village water operators rotate the

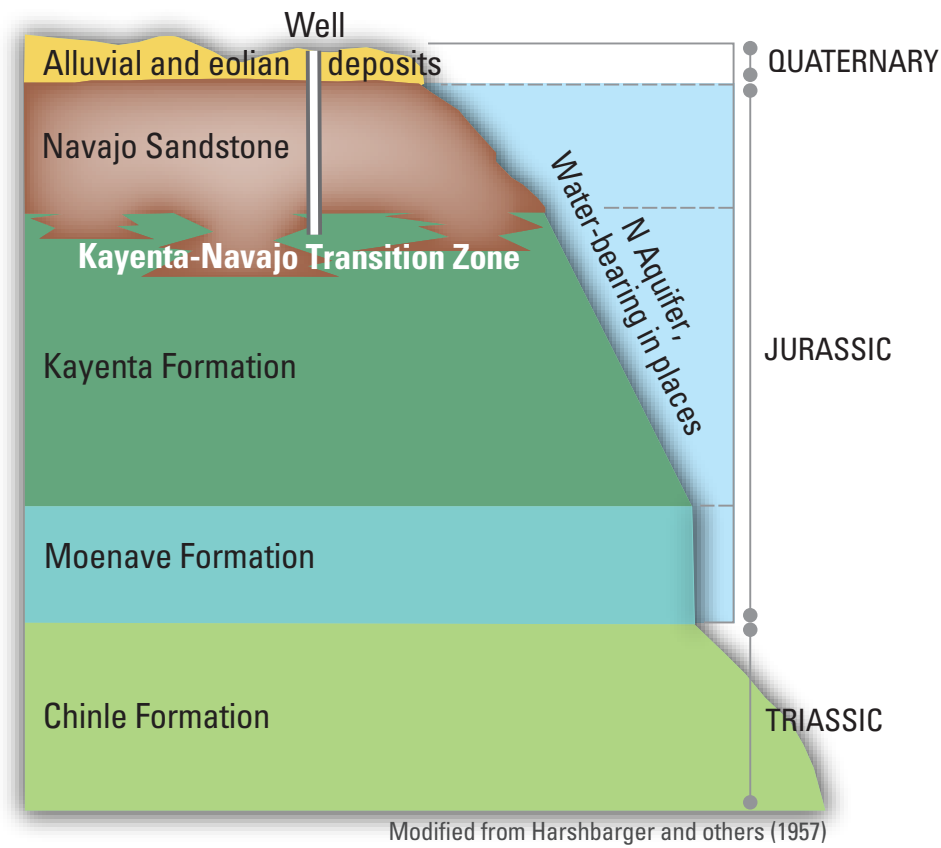

Figure 3. Generalized stratigraphic section for the area near the Upper Moenkopi Village water-supply wells, Coconino County, Arizona. 
operation of the pumps on a nearly daily basis. The larger than predicted drawdown in the three wells and the resulting short column of water in the wells under pumping conditions - even during low pumping rates of $10-25 \mathrm{gal} / \mathrm{min}$ - resulted in the collection of fewer water-quality samples and prevented the collection of meaningful well-bore flow data.

\section{Methods of Study}

\section{Depth-Dependent Sampling and Well-Bore Flow}

Coupled well-bore flow and depth-dependent waterquality data that were collected from wells under pumping conditions can be used to directly measure the vertical distribution of flow and contaminants into wells from aquifers. Recent advancements in interpretation of these data use numerical groundwater-flow models and particle tracking at the well-bore scale to estimate aquifer hydraulic properties, and to predict the change in well yield and quality with changes in well construction (Halford, 2009). Collection of coupled well-bore flow and depth-dependent water-quality data can facilitate redesign of existing wells to improve water quality, or guide construction of future wells to ensure suitable-quality water (Izbicki and others, 1999).

Depth-dependent water samples were collected by the USGS from the three water-supply wells, (MSW-1, MSW-2, and MSW-3) for May 5-13, 2010. The samples were collected under pumping conditions to determine if there is a vertical distribution of water entering the wells from the surrounding aquifer. Depth-dependent samples were collected from the three production wells under pumping conditions using a gasdisplacement sample pump (Izbicki, 2004). The pump used in this study is about $6 \mathrm{in}$. long, less than $1 \mathrm{in}$. in diameter, and operated through repeated application and release of compressed gas. The pump is intended for use in production wells having limited access that prevents the use of traditional geophysical tools (such as wire-line bailers) used to collect depth-dependent water samples. Data collected at different depths within the production well reflect water quality at those depths under actual pumping conditions.

The original scope of work called for the collection of water-quality samples at three positions within the water column of each well under pumping conditions - at the top, midpoint, and bottom portions of the screened interval. However, owing to the larger than predicted drawdown in the three wells and the resulting short column of water available to sample from in each well, a decision was made to collect water-quality samples from two positions in each well-at the top and bottom portions of the available water column.

The perforated interval within MSW-1 consists of a $60 \mathrm{ft}$ section of 8-in. perforated steel casing from 69 to $129 \mathrm{ft}$ below the top of the well casing (table 1). The pumping depth-towater was about $99 \mathrm{ft}$ on April 28, 2010, thus about one-half of the perforated interval is above the water column under pumping conditions. This information guided the collection of water samples at MSW-1 - samples were collected from a depth of $105 \mathrm{ft}$ near the top of the water column and from a depth of $120 \mathrm{ft}$ near the bottom of the perforated interval. MSW-2 has two perforated intervals, the first from 72 to 77 $\mathrm{ft}$ and the second from 105 to $125 \mathrm{ft}$ below the top of the well casing (table 1). Both perforated intervals consist of 8 -in. stainless steel well screen. The pumping depth-to-water was about $100 \mathrm{ft}$ on April 28, 2010 - causing the upper perforated interval to be exposed above the water column under pumping conditions. Water samples from MSW-2 were collected from a depth of $107 \mathrm{ft}$ near the top of the water column and from a depth of $120 \mathrm{ft}$ near the bottom of the lower perforated interval. MSW-3 has four perforated intervals, the first from 71 to $81 \mathrm{ft}$, the second from 125 to $145 \mathrm{ft}$, the third from 166 to $176 \mathrm{ft}$, and the fourth from 226 to $236 \mathrm{ft}$ below the top of the well casing (table 1). The four perforated intervals consist of 8 -in. stainless steel well screen. The pumping depthto-water was $88.5 \mathrm{ft}$ on April 28, 2010, causing the upper perforated interval to be exposed above the water column under pumping conditions. Water samples from MSW-3 were collected from a depth of $135 \mathrm{ft}$, within the zone of the second perforated interval, and from a depth of $230 \mathrm{ft}$, within the zone of the lowermost perforated interval.

An attempt was made to collect well-bore flow data under pumping conditions in the three wells using a technique called the "tracer-pulse method" (Izbicki and others, 1999). The method uses a high-pressure hose equipped with valves for dye injection. The hose is filled with fluid containing an easily measured tracer, such as water colored with Rhodamine dye. The hose is lowered to a known depth in the well and a pulse of the tracer is injected into the water column. The travel time of the tracer to a detector on the surface is measured. The hose is then lowered to a deeper depth and another pulse of dye is released. The velocity is calculated as the difference in the travel times. The flow rate, given a known well diameter, is then calculated. A series of dye injections are released at different depths to construct a velocity profile for the well. If successful, the velocity profile can be used to guide the collection and interpretation of depth-dependent water-quality data.

In addition to the limitations observed during the waterquality sampling, well construction issues with the three watersupply wells prevented the collection of meaningful well-bore flow data. At MSW-1 and MSW-2, the high-pressure hose used for dye injection could not be lowered past the top of the pump because the pumps were fitted with sand shrouds with diameters close to the inside diameter of the well casing, and the small space between the two would not allow for the passage of the dye-injection hose. At MSW-2 and MSW-3, leaking fittings in the discharge pipes at the top of the wells caused pumped water to cascade back into the wells, resulting in erroneous values in the well-bore flow data. Additionally, groundwater-level decline coupled with the relatively low permeability of the surrounding aquifer resulted in larger than predicted drawdown in the three wells. This resulted in a short column of water in the wells 
under pumping conditions, even during low pumping rates of $10-25 \mathrm{gal} / \mathrm{min}$. The combination of these factors prevented the collection of meaningful well-bore flow data.

\section{Water-Chemistry Data Collection and Analysis}

Sampling procedures followed standard protocols for collection and preservation established in the USGS National Field Manual for the Collection of Water Quality Data (U.S. Geological Survey, variously dated). The major ion, nutrient, and trace metal water samples were analyzed by the USGS National WaterQuality Laboratory in Denver, Colorado. The radiochemistry water samples were analyzed by the Eberline Analytical Services in Richmond, California, and the carbon- $14\left({ }^{14} \mathrm{C}\right)$ water samples were analyzed by the McLean Laboratory at the Woods Hole Oceanographic Institute in Woods Hole, Massachusetts.

Field parameters including temperature, $\mathrm{pH}$, and specific conductance were measured with a Hydrolab MS5 multiparameter water-quality monitoring probe (manufactured by Hach Hydromet). Dissolved-oxygen concentrations were measured with an InSitu Troll ${ }^{\circledR} 9500$ water-quality monitoring probe (InSitu, Inc.). The water-quality monitoring probes were calibrated each day of the sampling fieldwork. Titrations to determine total alkalinity and bicarbonate concentrations of the water samples were conducted in the field within 4 hours of sample collection using the inflection point method (Rounds, 2012). Buffer solutions for the titrations were provided by the USGS National Water Quality Laboratory and $\mathrm{pH}$ was measured during the titrations with a ThermoOrion $5 \mathrm{Star} \mathrm{pH}$ meter (Thermo Scientific Orion).

Chemical constituents from the water-supply wells were compared to the U.S. Environmental Protection Agency (USEPA) primary and secondary drinking-water standards (U.S. Environmental Protection Agency, 2009). Maximum contaminant levels (MCLs), which are the primary regulations, are legally enforceable standards that apply to public water systems. MCLs protect drinking-water quality by limiting the levels of specific contaminants that can adversely affect public health. Secondary maximum contaminant levels (SMCLs) provide guidelines for the control of contaminants that may cause cosmetic effects (such as skin or tooth discoloration) or aesthetic effects (such as taste, odor, or color) in drinking water. The USEPA recommends compliance with SMCLs for public water systems; however, compliance is not enforced (U.S. Environmental Protection Agency, 2009).

\section{Results of Water-Quality, Isotope, and Radiochemistry Analysis}

Results of the water-quality, stable isotope, and radiochemistry sample analyses are shown in tables 2 and 3 and also are available online at http://nwis.waterdata.usgs.gov/ az/nwis/qwdata by entering the USGS well site identification numbers listed in table 1. For comparison, table 2 also contains water-quality data for MSW-2 from samples collected in January 1992 and October 1993.

\section{Water Quality}

\section{Field Parameters and Inorganics}

At MSW-1, specific conductance was 533 and $603 \mu \mathrm{S} /$ $\mathrm{cm}$ for samples collected from the top and bottom portions of the water column, respectively. The $\mathrm{pH}$ was 8.7 and 7.3 for samples collected from the top and bottom portions of the water column, respectively. Dissolved oxygen was not determined for the sample collected from the top of the water column and was $5.75 \mathrm{mg} / \mathrm{L}$ for the sample collected from the bottom portion of the water column. The total dissolved solids (TDS) was $332 \mathrm{mg} / \mathrm{L}$ for the sample collected from the top portion of the water-column sample and slightly higher at $374 \mathrm{mg} / \mathrm{L}$ for the sample from the bottom portion of the water column. Alkalinity was similar for the two samples collected at MSW-1, measuring 135.1 and $136.5 \mathrm{mg} / \mathrm{L}$ for the samples collected from the top and bottom portions of the water column, respectively. At MSW-1, bicarbonate concentrations were 164.7 and $166.4 \mathrm{mg} / \mathrm{L}$ for samples collected from the top and bottom portions of the water column, respectively.

For MSW-2, specific conductance was 525 and 561 $\mu \mathrm{S} / \mathrm{cm}$ for the samples collected from the top and bottom portions of the water column, respectively. The $\mathrm{pH}$ was 8.06 and 7.19 for the samples collected from the top and bottom portions of the water column, respectively. Dissolved oxygen was not determined for the sample collected from the top of the water column; however, a value of $7.86 \mathrm{mg} / \mathrm{L}$ was measured for the sample collected from the lower portion of the water column. TDS was not determined for the sample collected from the top of the water column; however, a value of $318 \mathrm{mg} / \mathrm{L}$ was measured for the sample from the bottom portion of the water column. Alkalinity also was similar for the two samples collected at MSW-2-98.7 and $96.6 \mathrm{mg} / \mathrm{L}$ for the samples collected from the top and bottom portions of the water column, respectively. At MSW-2, bicarbonate concentrations were 120.3 and $117.8 \mathrm{mg} / \mathrm{L}$ for the samples collected from the top and bottom portions of the water column, respectively.

For MSW-3, specific conductance was 596 and 488 $\mu \mathrm{S} / \mathrm{cm}$ for the samples collected from the top and bottom portions of the water column, respectively. The $\mathrm{pH}$ was 8.6 for samples collected from the top and bottom portions of the water column. Dissolved oxygen was not determined for the sample collected from the top of the water column; however, a value of $5.3 \mathrm{mg} / \mathrm{L}$ was measured for the sample collected from the bottom portion of the water column. TDS was not determined for the sample collected from the top portion of the water column; however, a value of $303 \mathrm{mg} / \mathrm{L}$ was measured for the sample from the bottom portion of the water column. 
Alkalinity was similar for the two samples collected at MSW3, measuring 136.1 and $132.0 \mathrm{mg} / \mathrm{L}$ for the samples collected from the top and bottom portions of the water column, respectively. At MSW-3, bicarbonate concentrations were 157.3 and $135.1 \mathrm{mg} / \mathrm{L}$ for the samples collected from the top and bottom portions of the water column, respectively. None of the water samples collected at MSW-1, MSW-2, and MSW-3 and analyzed for TDS were greater than the USEPA SMCL standard of $500 \mathrm{mg} / \mathrm{L}$. The USEPA SMCL range for $\mathrm{pH}$ is $6.5-$ 8.5. At MSW-1, the $\mathrm{pH}$ for the sample collected from the top of the water column was 8.65 , slightly exceeding the SMCL. Additionally, at MSW-3, pH was 8.55 and 8.63 for the samples collected from the top and bottom portions of the water column, respectively. These $\mathrm{pH}$ values also slightly exceeded the USEPA SMCL and indicate that the water is alkaline.

The ratios of the major dissolved ions from the samples collected from MSW-1 and MSW-2 indicate water with a calcium and sulfate-ion composition (figs. $4 A$ and $4 B$; table 2 ). MSW-1 and MSW-2 are completed to similar depths in the Navajo Sandstone (table 1). There is not a significant vertical distribution of the major ion concentrations in the samples collected from the top and bottom portion of the water column in the two wells. Concentrations of the major dissolved ions for the four samples collected from MSW-1 and MSW-2 ranged from 49.9 to $56.5 \mathrm{mg} / \mathrm{L}$ for calcium, 30.8 to $44.5 \mathrm{mg} / \mathrm{L}$ for sodium, 11.3 to $13.3 \mathrm{mg} / \mathrm{L}$ for magnesium, 1.96 to 2.13 $\mathrm{mg} / \mathrm{L}$ for potassium, 41.6 to $52.7 \mathrm{mg} / \mathrm{L}$ for chloride, 0.15 to $0.29 \mathrm{mg} / \mathrm{L}$ for fluoride, and 62.5 to $81.7 \mathrm{mg} / \mathrm{L}$ for sulfate. The major ion concentrations for the samples collected at MSW-2 as part of this study are similar to the samples collected in January 1992 and October 1993 (table 2).

The samples collected at MSW-3 were higher in sodium and lower in calcium than the samples collected from MSW-1 and MSW-2 and contained a similar sulfate-ion percentage (fig. 4; table 2). MSW-3 is about $140 \mathrm{ft}$ deeper than MSW-1 and MSW-2, with the lower portion of the well completed in the Kayenta Formation-Navajo Sandstone transition zone (fig. 3). Additionally, there was a vertical distribution of ion concentrations in the samples collected at MSW-3. Calcium concentrations for the samples collected at MSW-3 were 30.6 $\mathrm{mg} / \mathrm{L}$ for the sample collected from the top portion of the water column ( $135 \mathrm{ft}$ below the top of the casing) and $8.21 \mathrm{mg} / \mathrm{L}$ for the sample collected from the bottom portion of the water column ( $230 \mathrm{ft}$ below the top of the casing). In contrast, the sodium concentration increased with depth in the water column. Sodium concentrations were 78.8 and $96.6 \mathrm{mg} / \mathrm{L}$ for the

Table 2. Water quality data from Upper Moenkopi Village water-supply wells, Coconino County, Arizona.

[--, no data; <, less than; E, estimated; R, radchem non-detect, below ssLc; mg/L, milligrams per liter; mm, millimeters; gpm, gallons per minute; $\mu \mathrm{s} / \mathrm{cm}$, microsiemens per centimeter; ${ }^{\circ} \mathrm{C}$, degrees Celsius]

\begin{tabular}{|c|c|c|c|c|c|c|c|c|c|}
\hline $\begin{array}{l}\text { Barometric } \\
\text { pressure, } \\
\text { (mm of } \\
\text { mercury) }\end{array}$ & $\begin{array}{c}\text { Dissolved } \\
\text { oxygen, } \\
\text { (mg/L) }\end{array}$ & $\begin{array}{c}\text { Flow rate, } \\
\text { (gpm) }\end{array}$ & $\begin{array}{c}\text { pH, field, } \\
\text { (standard } \\
\text { units) }\end{array}$ & $\begin{array}{c}\text { pH, } \\
\text { laboratory, } \\
\text { (standard } \\
\text { units) }\end{array}$ & $\begin{array}{c}\text { Specific } \\
\text { conductance, } \\
\text { ( } \mu \mathrm{S} / \mathrm{cm} \text { at } 25 \\
\left.{ }^{\circ} \mathrm{C}\right)\end{array}$ & $\begin{array}{c}\text { Temperature, } \\
\left(25^{\circ} \mathrm{C}\right)\end{array}$ & $\begin{array}{l}\text { Depth of well, } \\
\text { feet below } \\
\text { land } \\
\text { surface datum }\end{array}$ & $\begin{array}{l}\text { Sampling } \\
\text { condition }\end{array}$ & $\begin{array}{l}\text { Sampling } \\
\text { method }\end{array}$ \\
\hline \multicolumn{10}{|c|}{ MSW-1, May 6, 2010} \\
\hline 633 & 5.8 & -- & 7.3 & 7.9 & 603 & 18.6 & -- & Pumping & $\begin{array}{c}\text { Submersible } \\
\text { pump }\end{array}$ \\
\hline \multicolumn{10}{|c|}{ MSW-1, May 13, 2010} \\
\hline-- & -- & -- & 8.7 & 8.2 & 533 & 18.4 & -- & Pumping & Other \\
\hline \multicolumn{10}{|c|}{ MSW-2, January 31, 1992} \\
\hline 574 & 5 & 100 & 8 & 7.9 & 589 & 16.3 & -- & -- & -- \\
\hline \multicolumn{10}{|c|}{ MSW-2, October 18, 1993} \\
\hline \multicolumn{10}{|c|}{ MSW-2, May 12, 2010} \\
\hline-- & -- & -- & 8.1 & 8.1 & 561 & 18.8 & -- & Pumping & Other \\
\hline \multicolumn{10}{|c|}{ MSW-3, May 6, 2010} \\
\hline 634 & 5.3 & -- & 8.6 & 9.2 & 488 & 19.9 & -- & Pumping & $\begin{array}{c}\text { Submersible } \\
\text { pump }\end{array}$ \\
\hline \multicolumn{10}{|c|}{ MSW-3, May 11, 2010} \\
\hline-- & -- & -- & 8.6 & 8.7 & 596 & 19.1 & -- & Pumping & Other \\
\hline
\end{tabular}


Table 2. Water quality data from Upper Moenkopi Village water-supply wells, Coconino County, Arizona.-Continued

\begin{tabular}{|c|c|c|c|c|c|c|c|c|c|}
\hline $\begin{array}{c}\text { Dissolved } \\
\text { solids dried } \\
\text { at } 180^{\circ} \mathrm{C} \text {, } \\
\text { (mg/L) }\end{array}$ & $\begin{array}{c}\text { Calcium, } \\
\text { (mg/L) }\end{array}$ & $\begin{array}{l}\text { Magnesium, } \\
\text { (mg/L) }\end{array}$ & $\begin{array}{l}\text { Potassium, } \\
\text { (mg/L) }\end{array}$ & $\begin{array}{l}\text { Sodium, } \\
\text { (mg/L) }\end{array}$ & $\begin{array}{l}\text { Alkalinity, } \\
\text { as calcium } \\
\text { carbonate } \\
\text { (mg/L) }\end{array}$ & $\begin{array}{c}\text { Bicarbonate, } \\
\text { (mg/L) }\end{array}$ & $\begin{array}{c}\text { Bromide, } \\
\text { (mg/L) }\end{array}$ & $\begin{array}{c}\text { Carbonate, } \\
\text { (mg/L) }\end{array}$ & $\begin{array}{c}\text { Chloride, } \\
\text { (mg/L) }\end{array}$ \\
\hline \multicolumn{10}{|c|}{ MSW-1, May 6, 2010} \\
\hline 374 & 56.5 & 13.3 & 2.13 & 44.5 & 136 & 166 & 0.431 & -- & 52.7 \\
\hline 332 & 49.9 & 11.3 & 1.99 & 40 & 135 & 165 & 0.336 & -- & 41.6 \\
\hline \multicolumn{10}{|c|}{ MSW-2, January 31, 1992} \\
\hline 345 & 56 & 13 & 2.1 & 42 & 130 & 159 & -- & 0 & 59 \\
\hline \multicolumn{10}{|c|}{ MSW-2, October 18, 1993} \\
\hline 290 & 51 & 12 & 1.9 & 36 & 104 & 127 & -- & 0 & 48 \\
\hline-- & 52.4 & 11.9 & 1.99 & 30.8 & 98.7 & 120 & 0.538 & -- & 59.2 \\
\hline \multicolumn{10}{|c|}{ MSW-3, May 6, 2010} \\
\hline 303 & 8.21 & 2.09 & 1.16 & 96.6 & 132 & 135 & 0.128 & 12.7 & 31.5 \\
\hline \multicolumn{10}{|c|}{ MSW-3, May 11, 2010} \\
\hline-- & 30.6 & 7.57 & 1.71 & 78.8 & 136 & 157 & 0.373 & 4.2 & 51 \\
\hline
\end{tabular}

Table 2. Water quality data from Upper Moenkopi Village water-supply wells, Coconino County, Arizona.-Continued

\begin{tabular}{|c|c|c|c|c|c|c|c|c|c|}
\hline \multirow[b]{2}{*}{$\begin{array}{l}\text { Fluoride, } \\
\text { (mg/L) }\end{array}$} & \multirow[b]{2}{*}{$\begin{array}{c}\text { Silica, } \\
\text { (mg/L) } \\
\text { as } \mathrm{SiO}_{2}\end{array}$} & \multirow[b]{2}{*}{$\begin{array}{c}\text { Sulfate, } \\
\text { (mg/L) }\end{array}$} & \multicolumn{4}{|c|}{ As nitrogen (mg/L) } & \multicolumn{2}{|c|}{ As phosphorus (mg/L) } & \multirow[b]{2}{*}{$\begin{array}{c}\text { Aluminum, } \\
(\mu \mathrm{g} / \mathrm{L})\end{array}$} \\
\hline & & & $\begin{array}{c}\text { Ammonia } \\
\text { plus organic } \\
\text { nitrogen }\end{array}$ & Ammonia & $\begin{array}{c}\text { Nitrate } \\
\text { plus nitrite }\end{array}$ & Nitrite & $\begin{array}{c}\text { Ortho } \\
\text { phosphate }\end{array}$ & $\begin{array}{l}\text { Phospho- } \\
\text { rus }\end{array}$ & \\
\hline \multicolumn{10}{|c|}{ Moenkopi water-supply well name and sample date } \\
\hline \multicolumn{10}{|c|}{ MSW-1, May 6, 2010} \\
\hline 0.24 & 14.4 & 81.7 & 0.21 & $<.020$ & 1.24 & $<.002$ & 0.011 & $<.04$ & $<3.4$ \\
\hline 0.29 & 13.6 & 62.5 & $<.10$ & $<.020$ & 1.07 & $<.002$ & 0.01 & $<.04$ & $<3.4$ \\
\hline \multicolumn{10}{|c|}{ MSW-2, January 31, 1992} \\
\hline 0.3 & 14 & 80 & -- & 0.01 & 1.2 & $<.010$ & $<.01$ & -- & -- \\
\hline \multicolumn{10}{|c|}{ MSW-2, October 18, 1993} \\
\hline \multicolumn{10}{|c|}{ MSW-2, May 12, 2010} \\
\hline 0.16 & 13.1 & 81.7 & 0.1 & $<.020$ & 2.24 & E .001 & 0.01 & $<.04$ & $<3.4$ \\
\hline \multicolumn{10}{|c|}{ MSW-3, May 6, 2010} \\
\hline 0.94 & 12.1 & 51.1 & E.05 & $<.020$ & 1.63 & $<.002$ & 0.029 & E.02 & 7 \\
\hline \multicolumn{10}{|c|}{ MSW-3, May 11, 2010} \\
\hline 0.58 & 13.6 & 86.9 & 0.14 & $<.020$ & 1.84 & $<.002$ & 0.039 & $<.04$ & 5.1 \\
\hline
\end{tabular}


Table 2. Water quality data from Upper Moenkopi Village water-supply wells, Coconino County, Arizona._-Continued

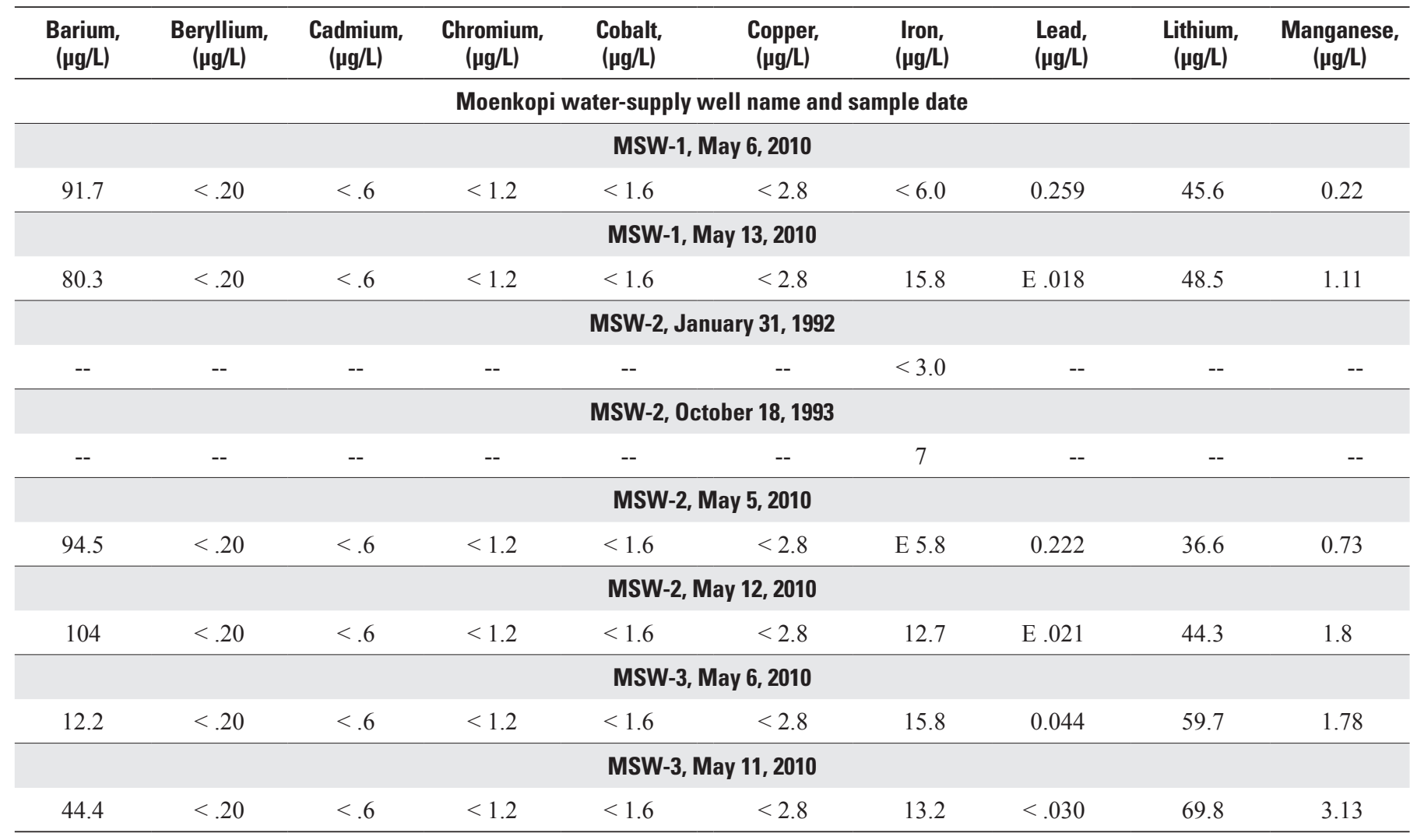

Table 2. Water quality data from Upper Moenkopi Village water-supply wells, Coconino County, Arizona._Continued

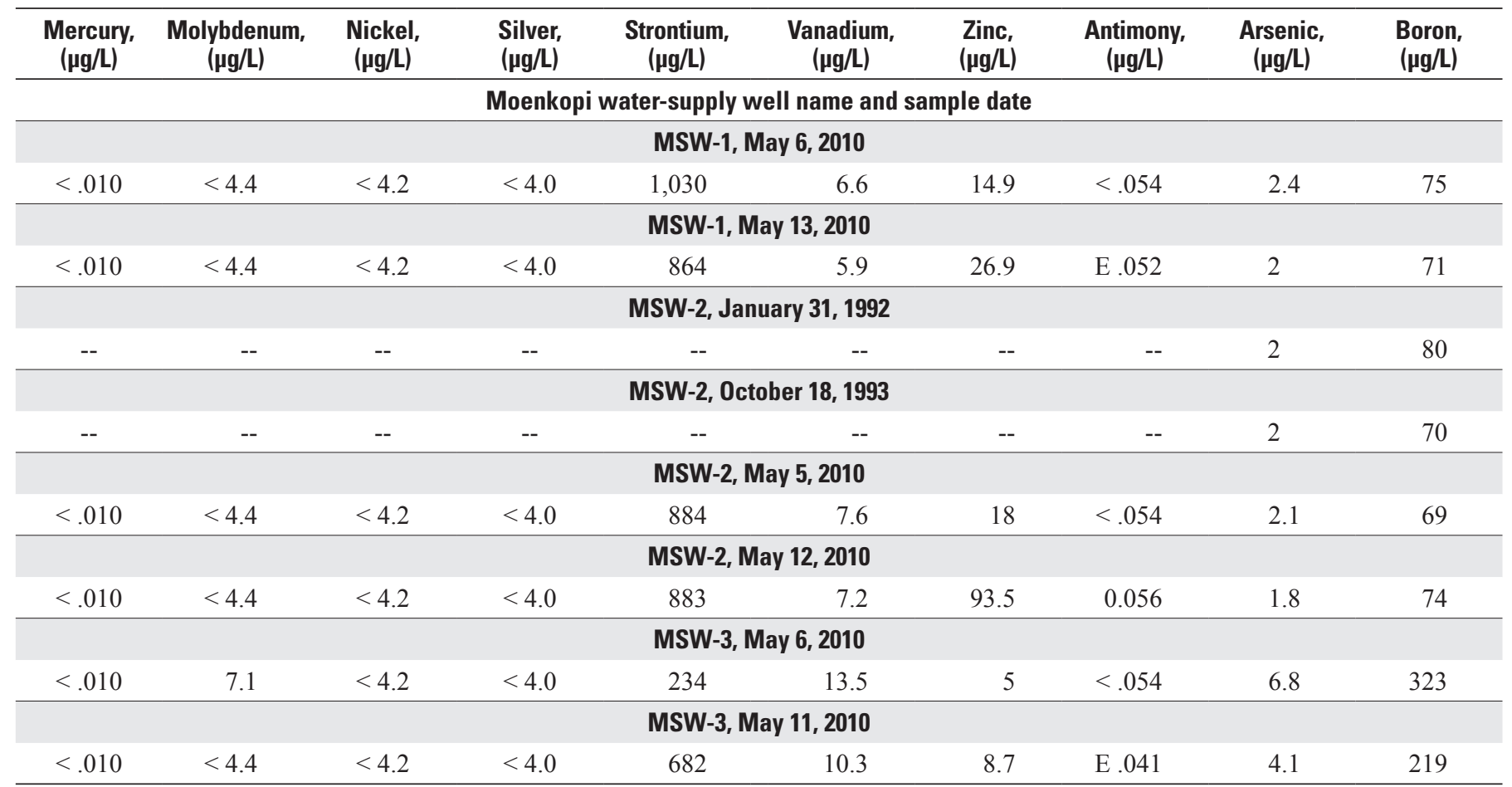


Table 2. Water quality data from Upper Moenkopi Village water-supply wells, Coconino County, Arizona.-Continued

\begin{tabular}{|c|c|c|c|c|c|c|c|c|c|c|}
\hline \multirow{2}{*}{$\begin{array}{l}\text { Selenium, } \\
(\mu \mathrm{g} / \mathrm{L})\end{array}$} & \multirow{2}{*}{$\begin{array}{c}\text { Organic } \\
\text { carbon, } \\
\text { (mg/L) }\end{array}$} & \multicolumn{3}{|c|}{$\begin{array}{l}\text { Suspended sediment, } \\
\text { dry weight, (pC/gm) }\end{array}$} & \multicolumn{2}{|c|}{$\begin{array}{c}\text { Carbon-14 (percent } \\
\text { modern) }\end{array}$} & \multicolumn{2}{|c|}{$\begin{array}{l}\text { Gross alpha activity } \\
\text { curve }(\mathrm{pC} / \mathrm{L})\end{array}$} & \multicolumn{2}{|c|}{$\begin{array}{l}\text { Gross beta activity } \\
\text { curve }(\mathrm{pC} / \mathrm{L})\end{array}$} \\
\hline & & $\begin{array}{l}\text { Uranium- } \\
234\end{array}$ & $\begin{array}{l}\text { Uranium- } \\
\quad 235\end{array}$ & $\begin{array}{l}\text { Uranium- } \\
\quad 238\end{array}$ & $\begin{array}{l}\text { Counting } \\
\text { error, filtered }\end{array}$ & Filtered & $\begin{array}{l}\text { 30-day } \\
\text { count, } \\
\text { Th-230 }\end{array}$ & $\begin{array}{c}\text { 72-hour } \\
\text { count, } \\
\text { Th-230 }\end{array}$ & $\begin{array}{l}\text { 30-day } \\
\text { count, } \\
\text { Cs-137 }\end{array}$ & $\begin{array}{c}\text { 72-hour } \\
\text { count, } \\
\text { Cs-137 }\end{array}$ \\
\hline \multicolumn{11}{|c|}{ Moenkopi water-supply well name and sample date } \\
\hline \multicolumn{11}{|c|}{ MSW-1, May 6, 2010} \\
\hline 2.1 & 0.72 & 0.005 & R -.0003 & 0.0036 & 0.26 & 69.27 & 7.3 & 9.8 & 2.4 & 2.3 \\
\hline \multicolumn{11}{|c|}{ MSW-1, May 13, 2010} \\
\hline 1.4 & E.49 & 0.05 & R .02 & R. .000 & 0.24 & 67.34 & 6 & 7.2 & 2.4 & 1.4 \\
\hline \multicolumn{11}{|c|}{ MSW-2, January 31, 1992} \\
\hline-- & -- & -- & -- & -- & -- & -- & -- & -- & -- & -- \\
\hline \multicolumn{11}{|c|}{ MSW-2, October 18, 1993} \\
\hline-- & -- & -- & -- & -- & -- & -- & -- & -- & -- & -- \\
\hline \multicolumn{11}{|c|}{ MSW-2, May 5, 2010} \\
\hline 3.5 & 0.82 & 0.0031 & R .0000 & 0.0012 & 0.22 & 65.2 & 5.1 & 8.1 & 2.8 & 1.6 \\
\hline \multicolumn{11}{|c|}{ MSW-2, May 12, 2010} \\
\hline 3.9 & 0.97 & R -.009 & $\mathrm{R}-.011$ & R.009 & 0.23 & 65.24 & 6.4 & 8.7 & 2.6 & 1.9 \\
\hline \multicolumn{11}{|c|}{ MSW-3, May 6, 2010} \\
\hline 1.1 & E.64 & 0.0078 & R.0004 & 0.003 & 0.18 & 33.44 & 6.4 & 5.1 & 1.4 & 1.3 \\
\hline \multicolumn{11}{|c|}{ MSW-3, May 11, 2010} \\
\hline 2.2 & 1.1 & $\mathrm{R}-.03$ & R -.031 & R .000 & 0.2 & 52.72 & 8.6 & 9.1 & 2.3 & 0.9 \\
\hline
\end{tabular}

Table 2. Water quality data from Upper Moenkopi Village water-supply wells, Coconino County, Arizona.-Continued

\begin{tabular}{|c|c|c|c|c|c|c|c|}
\hline $\begin{array}{l}\text { Thorium-228, } \\
\text { (pC/L) }\end{array}$ & $\begin{array}{c}\text { Thorium-230, } \\
\text { (pC/L) }\end{array}$ & $\begin{array}{l}\text { Thorium-232, } \\
\text { (pC/L) }\end{array}$ & $\begin{array}{l}\text { Tritium, } \\
\text { (pC/L) }\end{array}$ & $\begin{array}{l}\text { Uranium (natural), } \\
\qquad(\mu \mathrm{g} / \mathrm{L})\end{array}$ & $\begin{array}{c}\delta \text { Carbon-13, } \\
\text { (per mil) }\end{array}$ & $\begin{array}{c}\delta \text { Oxygen-18, } \\
\text { (per mil) }\end{array}$ & $\begin{array}{l}\text { Deuterium/pro- } \\
\text { tium ratio, } \\
\text { (per mil) }\end{array}$ \\
\hline \multicolumn{8}{|c|}{ Moenkopi water-supply well name and sample date } \\
\hline \multicolumn{8}{|c|}{ MSW-1, May 6, 2010} \\
\hline $\mathrm{R}-.01$ & R .02 & R .000 & R .1 & 3.85 & -8.04 & -8.61 & -74.7 \\
\hline \multicolumn{8}{|c|}{ MSW-1, May 13, 2010} \\
\hline 0.04 & 0.09 & R .000 & R.3 & 3.16 & -7.1 & -8.73 & -74.7 \\
\hline \multicolumn{8}{|c|}{ MSW-2, January 31, 1992} \\
\hline-- & -- & -- & -- & -- & -- & -- & -- \\
\hline \multicolumn{8}{|c|}{ MSW-2, October 18, 1993} \\
\hline-- & -- & -- & -- & -- & -- & -- & -- \\
\hline \multicolumn{8}{|c|}{ MSW-2, May 5, 2010} \\
\hline $\mathrm{R}-.02$ & R.01 & R .000 & $\begin{array}{r}1.3 \\
0.41 \mathrm{TU})\end{array}$ & 3.4 & -8.06 & -9.03 & -74.9 \\
\hline \multicolumn{8}{|c|}{ MSW-2, May 12, 2010} \\
\hline 0.07 & $\mathrm{R}-.10$ & R. .000 & R.3 & 3.52 & -8.03 & -9.09 & -75.5 \\
\hline \multicolumn{8}{|c|}{ MSW-3, May 6, 2010} \\
\hline R.01 & $\mathrm{R}-.01$ & 0.034 & $\mathrm{R}-.7$ & 4.51 & -7.52 & -9.52 & -79.1 \\
\hline \multicolumn{8}{|c|}{ MSW-3, May 11, 2010} \\
\hline 0.15 & $\mathrm{R}-.05$ & R. .000 & $\mathrm{R}-.2$ & 4.88 & -8.37 & -9.12 & -76.7 \\
\hline
\end{tabular}


Figure 4. Trilinear diagram showing relative compositions of groundwater samples collected from the Upper Moenkopi Village water-supply wells in Coconino County, Arizona, under pumping conditions; $A$. Well MSW-1; $B$. Well MSW2; C. Well MSW-3.

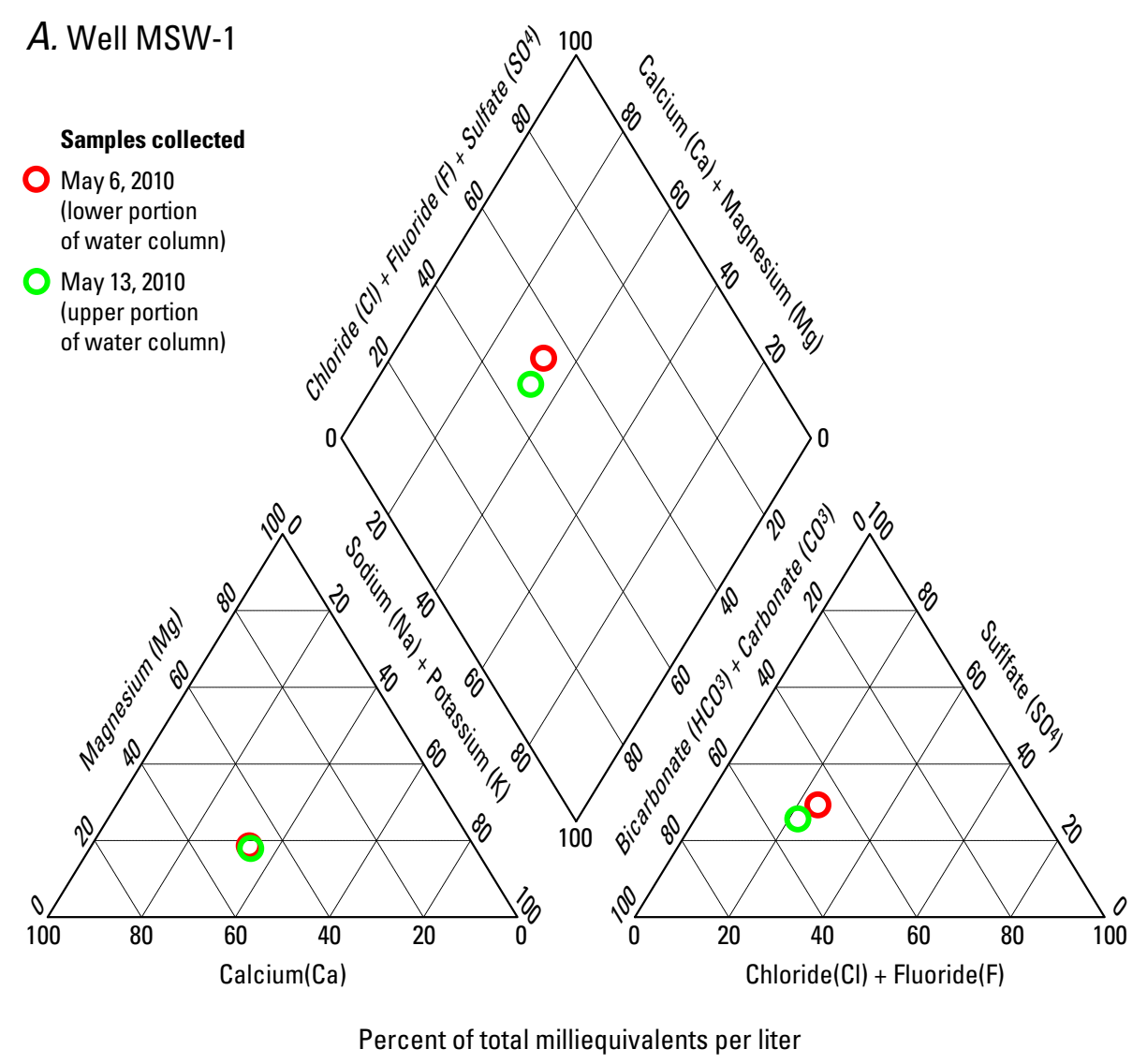

\section{B. Well MSW-2 \\ Samples collected \\ O January 31,1992 \\ October 18,1993 \\ May 5, 2010 \\ (upper portion of water column) \\ - May 12,2010 (lower portion of water column)}
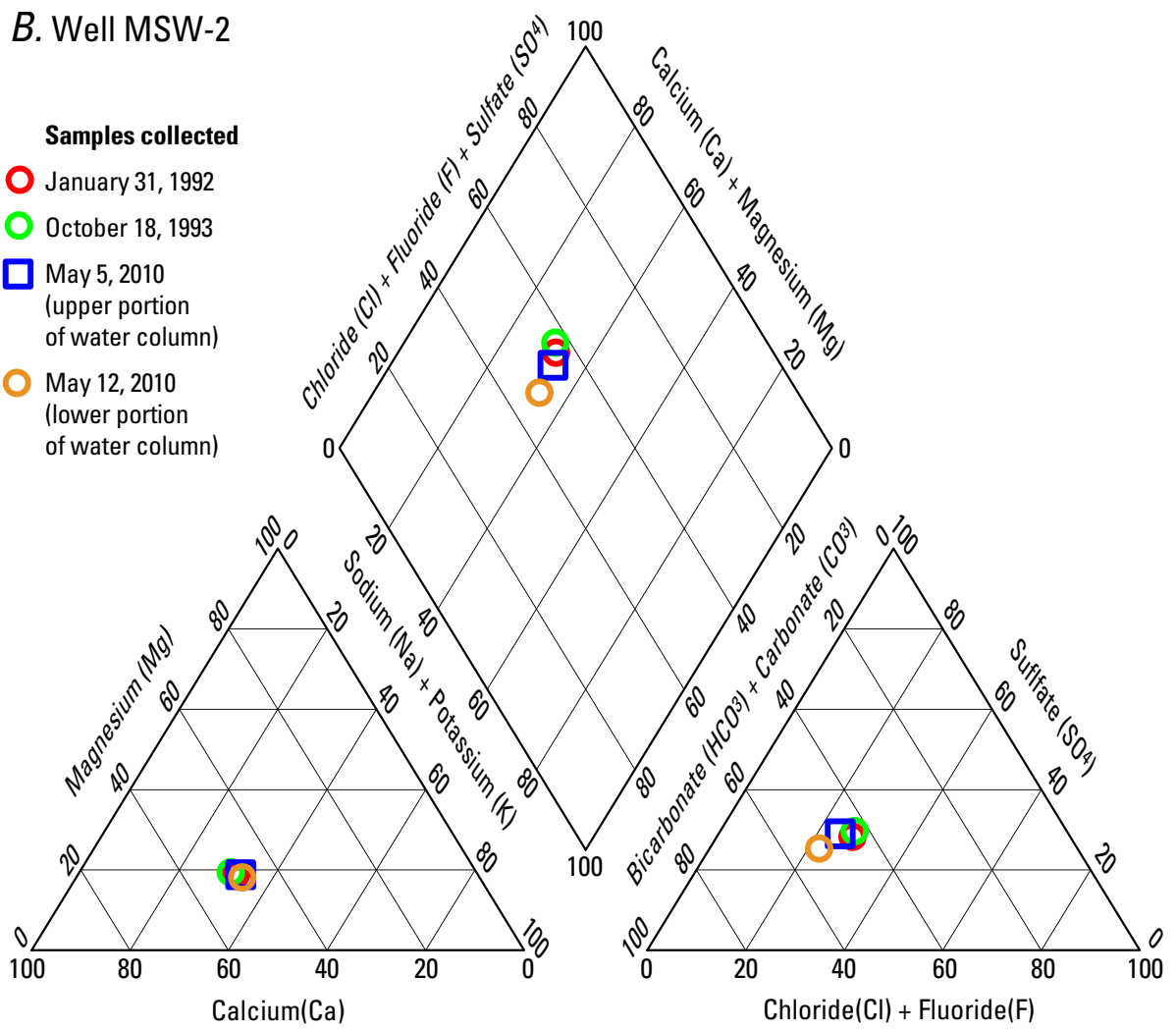

Percent of total milliequivalents per liter 
Figure 4.-Continued

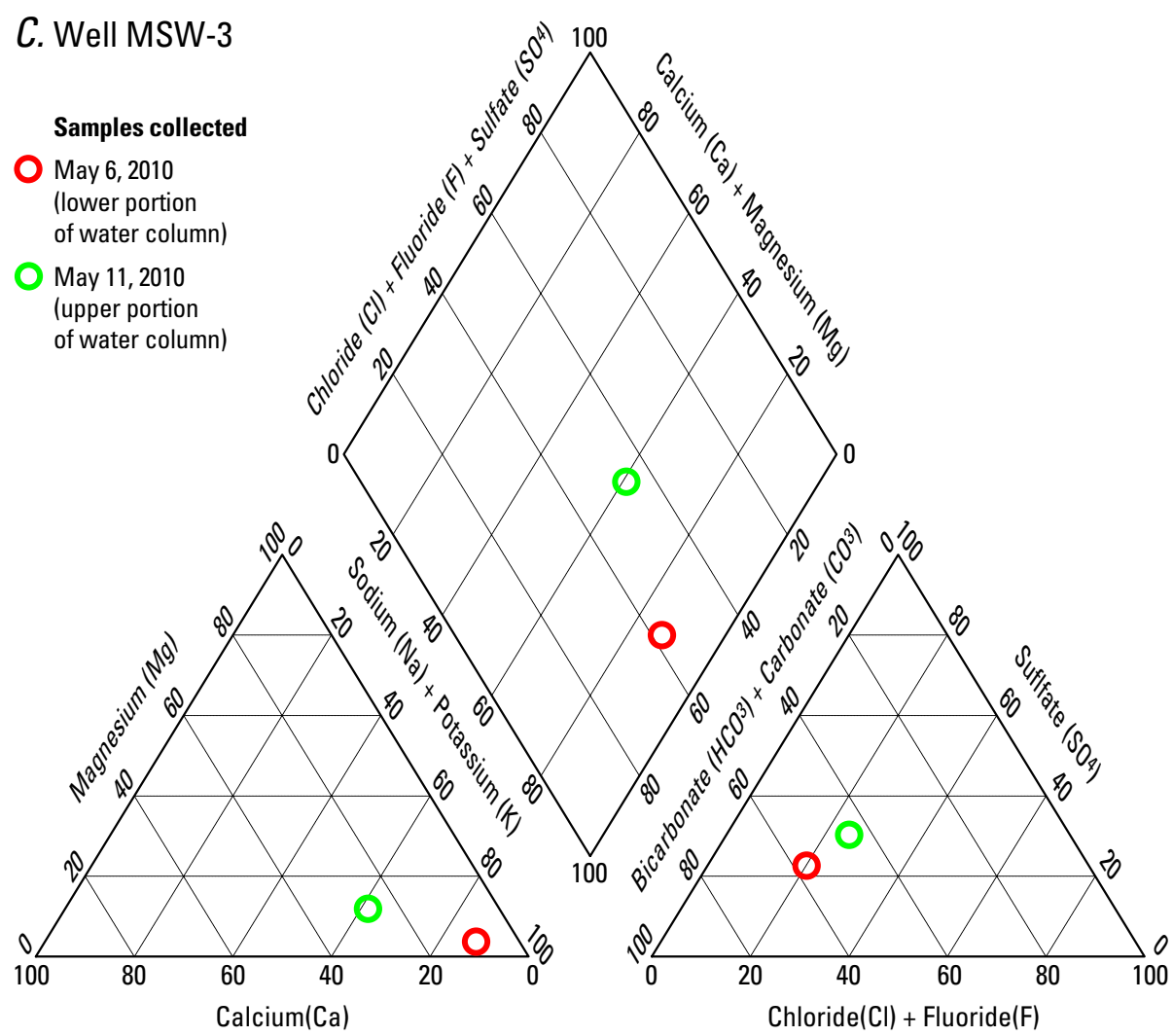

Percent of total milliequivalents per liter

samples collected from the top and bottom portions of the water column, respectively. Magnesium concentrations decreased from 7.57 to $2.09 \mathrm{mg} / \mathrm{L}$ for the samples collected from the top and bottom portions of the water column, respectively. Potassium concentrations were 1.71 and $1.16 \mathrm{mg} / \mathrm{L}$ for the samples collected from the top and bottom portions of the water column, respectively. Carbonate increased from 4.2 to $12.7 \mathrm{mg} / \mathrm{L}$ for the samples collected from the top and bottom portions of the water column, respectively. Chloride decreased from 51 to $31.5 \mathrm{mg} / \mathrm{L}$ for the samples collected from the top and bottom portions of the water column, respectively. Fluoride concentrations were higher for the samples collected at MSW-3 than the samples collected at MSW-1 and MSW-2, and increased with depth from 0.58 to $0.94 \mathrm{mg} / \mathrm{L}$ for the samples collected from the bottom portion of the water column. Sulfate concentrations for the samples collected at MSW-3 decreased with depth from 86.9 to 51.1 $\mathrm{mg} / \mathrm{L}$ for the samples collected from the top and bottom portions of the water column, respectively.

Previous studies of the Navajo Sandstone and the Kayenta Formation-Navajo Sandstone transition zone portions of the $\mathrm{N}$ aquifer generally reported calcium bicarbonate to sodium bicarbonate type water with low-to-moderate TDS and other trace elements (Cooley and others, 1969; Eychaner, 1983; Lopes and Hoffmann, 1997; Tetra Tech EM Inc., 2004; Carruth and Bills, 2012). Additionally, Cooley and others (1969) reviewed 140 groundwater samples from the Navajo Sandstone and found the principal chemical constituents to be calcium and sodium, and bicarbonate, sulfate, and chloride ions. TDS of the 140 samples ranged from about 90 to $1,000 \mathrm{ppm}$, and the most common minor chemical constituents were fluoride, nitrate, magnesium, silica, and iron.

\section{Nutrients}

Nutrients including nitrogen, phosphorus, and ammonia compounds can be a water-quality concern in concentrations that exceed USEPA MCLs. Major sources of nutrients include fertilizers, sewage effluent, and dissolution of naturally occurring minerals (Mueller and Helsel, 1996). For the samples collected at MSW-1, MSW-2, and MSW-3, nitrate (as nitrogen) ranged from 1.07 to $2.24 \mathrm{mg} / \mathrm{L}$ - less than the USEPA MCL of $10 \mathrm{mg} / \mathrm{L}$. Additionally, concentrations of nitrite (as nitrogen), orthophosphate (as phosphorus), phosphorus, and ammonia (as nitrogen) generally were low or less than detection limits for samples from all three water-supply wells (table 2). None of the water samples collected at MSW-1, MSW-2, and MSW-3 exceeded the USEPA MCL standards for nutrients (U.S. Environmental Protection Agency, 2009). 
Table 3. Carbon-14 radioisotope data used to estimate ages of groundwater sampled from the upper Moenkopi Village water-supply wells, Coconino County, Arizona.

[--, no data; pM, percent modern carbon; $\mathrm{mg} / \mathrm{L}$, milligrams per liter; mm, millimeters; gpm, gallons per minute; $\mu \mathrm{s} /$ $\mathrm{cm}$, microsiemens per centimeter; ${ }^{\circ} \mathrm{C}$, degrees Celsius]

\begin{tabular}{|c|c|c|c|c|c|}
\hline \multicolumn{2}{|c|}{ Carbon-14, normalized } & \multicolumn{2}{|c|}{ Carbon-14, de-normalized } & \multicolumn{2}{|c|}{$\begin{array}{c}\text { Calculated Carbon-14 } \\
\text { age, in years before present }\end{array}$} \\
\hline pM, & Error $1 \sigma \mathrm{pM}$ & pM, & Error $1 \sigma p M$ & normalized & de-normalized \\
\hline \multicolumn{6}{|c|}{ Moenkopi water-supply well name and sample date } \\
\hline \multicolumn{6}{|c|}{ MSW-1, May 6, 2010} \\
\hline 67.34 & 0.24 & 69.84 & 0.24 & 3176 & 2884 \\
\hline \multicolumn{6}{|c|}{ MSW-1, May 13, 2010} \\
\hline 69.27 & 0.26 & 71.70 & 0.26 & 2949 & 2672 \\
\hline \multicolumn{6}{|c|}{ MSW-2, May 5, 2012} \\
\hline 65.24 & 0.23 & 67.53 & 0.23 & 3431 & 3154 \\
\hline \multicolumn{6}{|c|}{ MSW-2, May 12, 2012} \\
\hline 65.2 & 0.22 & & & 3436 & \\
\hline \multicolumn{6}{|c|}{ MSW-3, May 6, 2010} \\
\hline 52.72 & 0.2 & 54.53 & 0.20 & 5143 & 4871 \\
\hline \multicolumn{6}{|c|}{ MSW-3, May 11, 2010} \\
\hline 33.44 & 0.18 & 34.65 & 0.18 & 8799 & 8514 \\
\hline
\end{tabular}

\section{Trace Elements}

The samples collected from MSW-1, MSW-2, and MSW-3 also were analyzed for selected trace elements, some of which can cause negative health effects if there is long-term exposure above the USEPA MCL (U.S.

Environmental Protection Agency, 2009). Samples from the three water-supply wells analyzed for arsenic did not contain concentrations that exceeded the USEPA MCL of $10 \mu \mathrm{g} / \mathrm{L}$. Arsenic concentrations ranged from 1.8 to $2.4 \mu \mathrm{g} / \mathrm{L}$ for the samples collected from MSW-1 and MSW-2. For MSW-3, arsenic concentrations ranged from 4.1 to $6.8 \mu \mathrm{g} / \mathrm{L}$ - the higher arsenic sample was collected from the bottom portion of the water column, $230 \mathrm{ft}$ below the top of the casing.

Uranium is an element of concern in the vicinity of Upper Moenkopi Village. Studies are ongoing to determine if elevated concentrations of uranium occur in the vicinity of the Tuba City Landfill and Open Dump Site and if groundwater from these sites could migrate toward the Upper Moenkopi Village water-supply wells (Morgan, 2002; Johnson and Wirt, 2009; Otton and others, 2009). Uranium is a naturally occurring radioactive element and can occur in groundwater when uranium deposits are present in the groundwater-flow system. Previous studies have indicated that uranium deposits occur at levels of economic importance in the surrounding area (Johnson and Wirt, 2009). Uranium ore mined from the Chinle Formation was processed in a nearby facility known as the Rare Metals Mill. In December 2003, the USEPA began regulating uranium in community water supplies in order to reduce the risk of cancer and kidney disease. For the samples collected from MSW-1 and MSW-2, uranium concentrations ranged from 3.16 to $3.85 \mu \mathrm{g} / \mathrm{L}$. For MSW-3, uranium concentrations ranged from 4.51 to $4.88 \mu \mathrm{g} / \mathrm{L}$. There is no significant vertical distribution of uranium concentrations in samples collected from the water-supply wells and no sample exceeded the USEPA MCL for uranium of $30 \mu \mathrm{g} / \mathrm{L}$ (table 2).

The samples collected from MSW-1, MSW-2, and MSW-3 were analyzed for other trace metals including aluminum, barium, chromium, copper, lead, mercury, nickel, selenium, silver, and zinc (table 2). Trace metals in groundwater may be derived from a variety of natural and anthropogenic sources. Many of these metals are required by humans in trace amounts but in larger, persistent dosages that exceed the USEPA MCL, these heavy metals can become toxic when they are not metabolized by the body (U.S. Environmental Protection Agency, 2009). None of the samples collected from MSW-1, MSW-2, or MSW-3 exceeded the USEPA MCL or SMCL for trace metals (table 2 and U.S. Environmental Protection Agency, 2009).

\section{Isotopes}

Water samples from the three water-supply wells were analyzed for a suite of environmental tracers that included the stable isotopes of oxygen and hydrogen, and radioactive isotopes of carbon and hydrogen. The isotope data can be used to develop and refine conceptual models of groundwaterflow systems. They also can be used to investigate sources 
of recharge and to determine rates of movement and ages of groundwater (Clark and Fritz, 1997).

The use of oxygen- $18\left({ }^{18} \mathrm{O}\right)$ and deuterium $\left({ }^{2} \mathrm{H}\right)$ stable isotopes are helpful in estimating groundwater recharge sources (Coplen, 1993). In general, water recharged under cooler climatic conditions is more depleted in ${ }^{18} \mathrm{O}$ and ${ }^{2} \mathrm{H}$; such stable isotope signatures have been observed in the nearby Black Mesa area (Truini and Longsworth, 2003). Additionally, evaporation during recharge and (or) evaporation from the top of the water table can produce a waterline with a lower slope (Coplen, 1993). Groundwater samples from the three Upper Moenkopi Village water-supply wells aligns with a local waterline (LWL) that is approximately parallel to the global meteoric water line (fig. 5). These signatures are similar to other reported data for shallow wells and springs in the area that discharge from $\mathrm{N}$ aquifer (Johnson and Wirt, 2009).

Sampling of the radioactive isotope of hydrogen $\left({ }^{3} \mathrm{H}\right.$ or tritium) was done to approximate the age of groundwater pumped by the wells. Tritium was released into the Earth's atmosphere in large quantities during nuclear bomb testing in the 1950s (Michel, 1989). The current level of tritium in the atmosphere in the Southwestern United States is approximately 5 tritium units (TU) (A. Manning, U.S. Geological Survey, oral commun., 2007). A surface-water sample in Pasture Canyon less than $0.5 \mathrm{mi}$ from the Moenkopi water-supply wells (fig. 2) had a tritium concentration of 4.9 $\mathrm{TU}$, which probably represents current exchange with the atmosphere (Johnson and Wirt, 2009). Water samples with values of tritium less than $1 \mathrm{TU}$ are interpreted to be primarily pre-bomb water (pre-1952). Samples with 1-2 TU may have a significant portion of pre-bomb water but also may have some post-bomb water due to mixing. All but one sample collected during this study had ${ }^{3} \mathrm{H}$ concentrations at or less than the detection limit for tritium and are interpreted to contain no modern water. The sample from the top of the water column in MSW-2 had a ${ }^{3} \mathrm{H}$ concentration of $1.3 \mathrm{pC} / \mathrm{L}(0.41 \mathrm{TU})$, indicating that composition is primarily pre-bomb (pre-1952), but may contain a small fraction of post-bomb modern water water (table 2).

Carbon-14 $\left({ }^{14} \mathrm{C}\right)$ is a naturally occurring radioactive isotope of carbon used to estimate the age of waters in the $500-50,000$ years before present range. Carbon- 14 is produced in the upper atmosphere as cosmic rays react with atmospheric nitrogen-14 $\left({ }^{14} \mathrm{~N}\right)$ to produce ${ }^{14} \mathrm{C}$ and hydrogen-1 $\left({ }^{1} \mathrm{H}\right)$. In the upper atmosphere, ${ }^{14} \mathrm{C}$ is rapidly oxidized to $\mathrm{CO}_{2}$ which readily mixes into the lower atmosphere. Any material using or reacting with atmospheric $\mathrm{CO}_{2}$ (plants and water) has a ${ }^{14} \mathrm{C}$ activity equal to atmospheric ${ }^{14} \mathrm{C}$ while it is in equilibrium with the atmospheric carbon reservoir (Pearson and White, 1967). Carbon-14 activity is reported as percent modern carbon (pmc) and, by convention, the modern pre1950 (pre-nuclear weapons testing) activity of atmospheric ${ }^{14} \mathrm{C}$ is $100 \mathrm{pmc}$.

Carbon-14 generally enters the hydrologic cycle through the following pathways: (1) dissolution of atmospheric $\mathrm{CO}_{2}$ into rainwater and surface water, (2) plant respired $\mathrm{CO}_{2}$ in the soil zone that dissolves into water, (3) $\mathrm{CO}_{2}$ resulting from oxidation of organic material in the soil that dissolves
Figure 5. Graph showing oxygen-18 $\left({ }^{18} \mathrm{O}\right)$ and deuterium $\left({ }^{2} \mathrm{H}\right)$ data from the Upper Moenkopi village water-supply wells and comparison with other water sources in the surrounding area, Coconino County, Arizona.

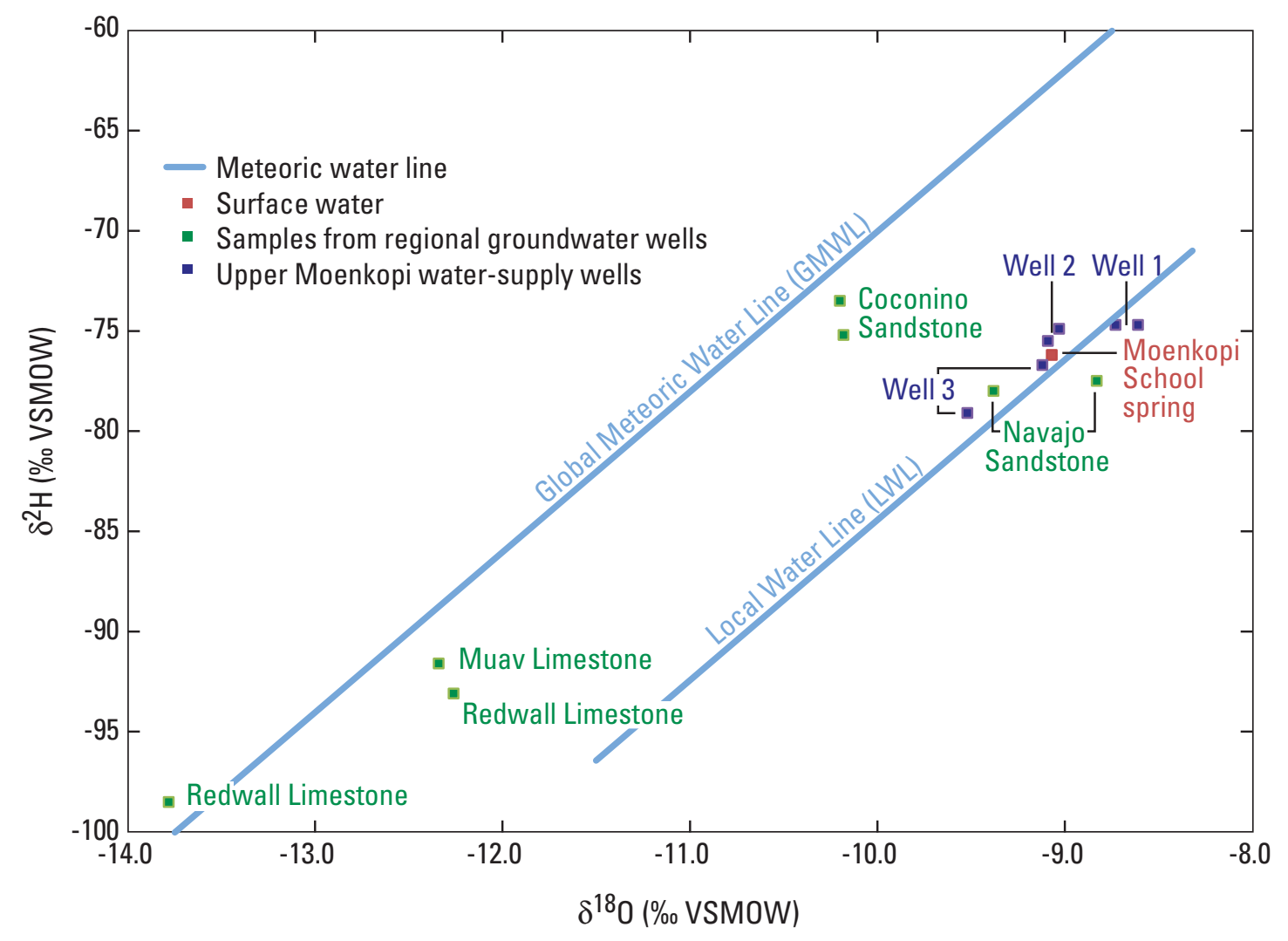


into water, and (4) dissolution of mineral phases containing geologically young carbon, particularly in carbonate rocks. Kalin (2000) provides a comprehensive review of the radiocarbon groundwater dating method. Table 3 shows the ${ }^{14} \mathrm{C}$ radioisotope data used to estimate ages of groundwater sampled from Upper Moenkopi Village water-supply wells. Data were used to estimate the pmc and ages of groundwater in the wells. The estimated ${ }^{14} \mathrm{C}$ age of groundwater in MSW-1 and MSW-2, both completed about $140 \mathrm{ft}$ into the Navajo Sandstone, is about 3,000 years before present. The estimated ${ }^{14} \mathrm{C}$ age of groundwater in MSW-3, completed about $240 \mathrm{ft}$ into the Navajo Sandstone-Kayenta Formation transition zone is older, about 5,000 years before present in the upper portion of the water column and about 8,500 years before present in the lower portion of the water column (table 3 ).

\section{Radiochemistry}

Radioactive elements are naturally present in a wide range of concentrations in rocks, soil, and water and the occurrence and distribution of radionuclides in groundwater is controlled primarily by the local geology and geochemistry (Zapecza and Szabo, 1988). In the vicinity of Upper

Moenkopi Village, uranium processed at the Rare Metals Mill (RMM) was not derived from the local Navajo Sandstone, but from the Chinle Formation near Cameron and from other formations in northeastern Arizona (Johnson and Wirt, 2009).

Measurements of gross alpha and beta activities serve as a useful screening technique that can provide information about natural and mined sources of radiation in the water supply and to estimate the corresponding potential public health impact. Gross alpha particle activity is a measure of the total amount of radioactivity in a water sample attributable to the radioactive decay of alpha-emitting elements. Gross alpha can be a concern for natural radioactivity in water as it refers to the radioactivity of uranium (U), thorium (Th), radium $(\mathrm{Ra})$, as well as radon $(\mathrm{Rn})$ and descendants (U.S. Environmental Protection Agency, 2009). Alpha particles are highly ionizing, but the particles travel short distances in air ( $<2$ in.) before being absorbed. Alpha particles have little ability to penetrate objects; thus, they can be stopped by a sheet of paper or the outer layer of skin. The external hazard from alpha particles is minimal, but the internal hazard when they are inhaled or ingested may be significant (U.S. Environmental Protection Agency, 2009). The USEPA MCL for gross alpha particle activity in drinking water is 15 pCi/L (U.S. Environmental Protection Agency, 2009). The gross alpha radioactivity of all samples collected from the three water-supply wells were less than the USEPA MCL and ranged from about 5.1 to $9.8 \mathrm{pCi} / \mathrm{L}$ (table 2).

Gross beta particle activity is a measure of the total amount of radioactivity in a water sample attributable to the radioactive decay of beta-emitting elements. Beta particles usually travel greater distances in air than alpha particles (about $6 \mathrm{ft}$ ) before being absorbed. Beta particles are more penetrating than alpha particles, and some are capable of penetrating the skin and causing radiation damage (U.S. Environmental Protection Agency, 2009). Gross beta particle activity is reported in $\mathrm{pCi} / \mathrm{L}$ as cesium-137 (Cs-137). The USEPA MCL for gross beta particle activity states that the average annual concentration of beta particle activity from radionuclides in drinking water shall not produce an annual dose equivalent to the total body or any internal organ greater than 4 millirems per year. The gross beta radioactivity of samples collected from the three water-supply wells are not considered elevated and ranged from about 0.9 to $2.8 \mathrm{pCi} / \mathrm{L}$ (table 2).

\section{Summary}

This report documents the collection and analysis of depth-dependent water samples under pumping conditions from the three public water-supply wells in Upper Moenkopi Village, referred to as MSW-1, MSW-2, and MSW-3. Samples from these wells were analyzed for a range of chemical and isotopic constituents including major ions, nutrients, trace elements, stable and radioactive isotopes, and radiochemistry. The study assessed the source, distribution of flow, and quality of water from each of the three public water-supply wells. Data collected during this study can be used to (1) assess the quality of the existing municipal water supply, (2) provide a baseline for comparison with future water-quality monitoring, (3) evaluate management options to address possible contaminant sources, and (4) provide information to design and locate future water-supply wells.

Previous hydrologic and geochemical investigations have determined that water supplies for the Upper Moenkopi Village are limited and vulnerable to potential sources of contamination including the Tuba City Landfill and a former uranium processing facility known as the Rare Metals Mill. Studies are ongoing to determine if uranium and other metals in groundwater beneath the landfill are greater than regional groundwater concentrations and if a flow path exists between the Tuba City Landfill area and the village water-supply wells.

Analyses of major ions, nutrients, selected trace metals, isotopes, and radiochemistry were done on the groundwater samples from the three wells to describe general waterquality conditions and groundwater ages in and immediately surrounding the Upper Moenkopi Village public-supply wells. Chemical constituents from the water-supply wells were compared to the U.S. Environmental Protection Agency (USEPA) primary and secondary drinking water standards. None of the water samples collected at MSW-1, MSW-2, and MSW-3 exceeded USEPA primary drinking water standards. The $\mathrm{pH}$ for a water sample collected from the top of the water column in MSW-1 measured 8.65, exceeding the USEPA secondary drinking water standard for a $\mathrm{pH}$ range of 6.5-8.5. Additionally, at MSW-3, the $\mathrm{pH}$ ranged from 8.55 and 8.63 
for the samples collected from the top and bottom portion of the water column - these $\mathrm{pH}$ values also exceeded the USEPA secondary drinking water standard.

The ratios of the major dissolved ions from the samples collected from MSW-1 and MSW-2 indicate water with a calcium and sulfate-ion composition and no significant vertical distribution of ion concentrations within the wells. Samples collected at MSW-3 are higher in sodium and lower in calcium than the samples collected from MSW-1 and MSW-2 and contain a similar sulfate-ion percentage. MSW-3 is about $140 \mathrm{ft}$ deeper than MSW-1 and MSW-2 and there is a vertical distribution of ion concentrations in the samples collected at the well.

Groundwater samples from the three water-supply wells analyzed for oxygen-18 and deuterium stable isotopes appear to align with a local water line that is approximately parallel to the global meteoric water line. Tritium concentrations in samples from MSW-1 and MSW-3 were at or less than laboratory detection limits; these samples were interpreted to contain no modern water. A sample from the top of the water column at MSW-2 had a tritium concentration of 0.41 tritium units, indicating that the composition is primarily pre-bomb (pre-1952) water, but may contain a small fraction of postbomb modern water.

The estimated carbon-14 age of groundwater sample from MSW-1 and MSW-2, both completed about 140 feet into the Navajo Sandstone, is about 3,000 years before present. The estimated carbon-14 age of groundwater sampled from MSW-3, completed about 240 feet into the Kayenta Formation-Navajo Sandstone transition zone is older, about 5,000 years before present in the top portion of the water column and about 8,500 years before present in the bottom portion of the water column. The gross alpha radioactivity of samples collected from the three water-supply wells ranged from 5.1 to 9.8 picocuries per liter ( $\mathrm{pCi} / \mathrm{L}$ ) - less than USEPA primary drinking water standard of $15 \mathrm{pCi} / \mathrm{L}$. The gross beta radioactivity of samples collected from the wells ranged from 0.9 to $2.8 \mathrm{pCi} / \mathrm{L}$ and are not considered elevated relative to the USEPA primary drinking water standard.

\section{Acknowledgments}

The authors thank William Charley, Governor of Upper Moenkopi Village, for providing logistical support, wellvideo logs, and well-operations technicians from his staff. Governor Charley also approved a contract on short notice with Flagstaff Well and Supply Company to replace a leaking pump column on MSW-2 and to remove the sand shrouds on MSW-1 and MSW-2 to allow for the collection of depth dependent water samples. Pete Mitchell of the Indian Health Service provided onsite logistical support and assistance. Hopi Water Resources Program Director, Lionel Puhuyesva, provided support for the project and valuable input during project meetings.

\section{References}

Brown, J.G., and Eychaner, J.H., 1988, Simulation of five ground-water withdrawal projections for the Black Mesa area, Navajo and Hopi Indian Reservations, Arizona: U.S. Geological Survey Water-Resources Investigations Report 88-4000, 56 p.

Carruth, R.L., and Bills, D.J., 2012, Aquifer test at well SMW-1 near Moenkopi, Arizona: U.S. Geological Survey Scientific Investigations Report 2012-5201, 11 p. (Also available at http://pubs.usgs.gov/ sir/2012/5201/.)

Clark, I., and Fritz, P., 1997, Environmental isotopes in hydrogeology: Boca Raton, Florida, CRC Press LLC, 328 p.

Cooley, M.E., Harshbarger, J.W., Akers, J.P., and Hardt, W.F., 1969, Regional hydrogeology of the Navajo and Hopi Indian Reservations, Arizona, New Mexico, and Utah, with a section on Vegetation, by O.N. Hicks: U.S. Geological Survey Professional Paper 521-A, 61 p., 9 plates.

Coplen, T.B., 1993, Uses of environmental isotopes, in Alley, V.M., Regional ground-water quality: New York, Van Nostrand Reinhold, 634 p.

Eychaner, J.H., 1983, Geohydrology and effects of water use in the Black Mesa area, Navajo and Hopi Indian Reservations, Arizona: U.S. Geological Survey WaterSupply Paper 2201, 26 p.

Farrar, C.D., 1980, Maps showing groundwater conditions in the Hopi Area, Coconino and Navajo Counties, Arizona;1977: U.S. Geological Survey Open-File Report 80-3, scale 1:250,000, 4 sheets.

Halford, Keith, 2009, AnalyzeHOLE - An integrated wellbore flow analysis tool: U.S. Geological Survey Techniques and Methods 4-F-2, 46 p.

Harshbarger, J.W., Repenning, C.A., and Irwin, J.H., 1957, Stratigraphy of the uppermost Triassic and the Jurassic rocks of the Navajo country: U.S. Geological Survey Professional Paper 291, 74 p.

Hoffmann, J.P., Bills, D.J., Phillips, J.V., and Halford, K.J., 2006, Geologic, hydrologic, and chemical data from the $\mathrm{C}$ aquifer near Leupp, Arizona: U.S. Geological Survey Scientific Investigations Report 2005-5280, 42 p.

Izbicki, J.A., Christensen, A.H., and Hanson, R.T., 1999, U.S. Geological Survey combined well-bore flow and depth-dependent water sampler: U.S. Geological Survey Fact Sheet 196-99, 2 p. (Also available at http://pubs. er.usgs.gov/usgspubs/fs/fs19699.) 
Izbicki, J.A., 2004, A small-diameter sample pump for collection of depth-dependent samples from production wells under pumping conditions. U.S. Geological Survey Fact Sheet 2004-3096, 2 p. (Also available at http://pubs.er.usgs. gov/usgspubs/fs/fs20043096.)

Johnson, R.H., and Wirt, L., 2009, Geochemical analyses of rock, sediment, and water from the region in and around the Tuba City Landfill, Tuba City, Arizona: U.S. Geological Survey Open-File Report 2009-1020, 44 p.

Kalin, R.M., 2000, Radiocarbon dating of groundwater systems, chap. 4 of Cook, P.G., and Herczeg A.L., eds., Environmental tracers in subsurface hydrology: Boston, Kluwer Academic Publishers, 529 p.

Levings, G.W., and Farrar, C.D., 1977, Map showing groundwater conditions in the southern part of the Black Mesa area, Navajo, Apache, and Coconino Counties, Arizona, 1976: U.S. Geological Survey Water-Resources Investigations Report 77-41, scale 1:250,000, 3 pls.

Lopes, T.J., and Hoffmann, J.P., 1997, Geochemical analyses of groundwater ages, recharge rates, and hydraulic conductivity of the $\mathrm{N}$ aquifer, Black Mesa area, Arizona: U.S. Geological Survey Water-Resources Investigations Report 96-4190, $42 \mathrm{p}$.

Macy, J.P., 2010, Groundwater, surface-water, and waterchemistry data, Black Mesa area, northeastern Arizona-2008-2009: U.S. Geological Survey Open-File Report 2010-1038, 43 p.

Macy, J.P., 2012, Characterization of subsurface geologic structure for potential water resources near the Villages of Moenkopi, Arizona, 2009-2010: U.S. Geological Survey Scientific Investigations Report 2012-5180, p 24. (Also available at http://pubs.usgs.gov/sir/2012/5180/.)

Macy, J.P., Brown, C.R., and Anderson, J.R., 2012, Groundwater, surface-water, and water-chemistry data, Black Mesa area, northeastern Arizona-2010-2011: U.S. Geological Survey Open-File Report 2012-1102, 41 p.

Michel, R.L., 1989, Tritium deposition over the continental United States, 1953-1983, in Atmospheric Deposition: International Association of Hydrological Sciences, p. 109-115.

Morgan, R., 2002, Rapid site characterization report-The Hopi Tribe Water Resources program: Prepared under the U.S. Environmental Protection Agency Resource and Conservation and Recovery Act Section 8001 Grant Project, 110 p.
Mueller, D.K., and Helsel, D.R., 1996, Nutrients in the nation's waters - Too much of a good thing?: U.S. Geological Survey Circular 1136, 24 p.

Otton, J.K., Johnson, R.H., and Horton, R.J., 2009, Geologic maps and cross sections of the Tuba City open dump site and vicinity, with implications for the occurrence and flow of ground water: U.S. Geological Survey Open-File Report 2008-1380, 78 p.

Pearson, F.J., and White, D.E., 1967, Carbon-14 ages and flow rates in Carrizo Sand, Atascosa County, Texas: Water Resources Research, v. 3, no. 1, p. 251-261.

Rounds, S.A., 2012, Alkalinity and acid neutralizing capacity (version 4.0), in Wilde, F.D., and Radtke, D.B., eds., National field manual for the collection of waterquality data: U.S. Geological Survey Techniques of Water-Resources Investigations, book 9, chap. A6, sec. 6.6, 45 p., accessed June 6, 2013 at http://water.usgs.gov/ owq/FieldManual/Chapter6/section6.6/.

Tetra Tech EM Inc., 2004, Water resource evaluation south of Moenkopi Wash, Moenkopi District of the Hopi Indian Reservation, Coconino County, Arizona: 13 p.

Truini, Margot, and Longsworth, S.A., 2003, Hydrogeology of the D aquifer and movement and ages of ground water determined from geochemical and isotopic analyses, Black Mesa area, northeastern Arizona: U.S. Geological Survey Water-Resources Investigations Report 2003$4189,38 \mathrm{p}$.

U.S. Department of Health and Human Services, 2008, Project summary, Moencopi well study, Hopi Indian Reservation, Navajo and Coconino Counties, Arizona: Project Number PH-D78, $10 \mathrm{p}$.

U.S. Environmental Protection Agency, 2009, National primary and secondary drinking water regulations: U.S.Environmental Protection Agency, EPA 816-F-09004, accessed June 6, 2013, at http://water.epa.gov/drink/ contaminants/index.cfm.

U.S. Geological Survey, variously dated, National field manual for the collection of water-quality data: U.S. Geological Survey Techniques of Water-Resources Investigations, book 9, chaps. A1-A9. (Also available at http://pubs.water.usgs.gov/twri9A.)

Zapecza, O.S., and Szabo, Zoltan, 1988, Radioactivity in ground water - a review: U.S. Geological Survey WaterSupply Paper 2325, p. 50-57. 
Menlo Park Publishing Service Center, California

Manuscript approved for publication July 10, 2013

Edited by John Buursma

Design and layout by Jeanne S. DiLeo 
